\title{
Translation as Import Substitution: the Portuguese Version of Véron de Forbonnais's Elémens du Commerce ${ }^{1}$
}

\author{
Monica Lupetti* \\ University of Pisa \\ Department of Philology, Literature and Linguistics \\ Marco E.L. Guidi* \\ University of Pisa \\ Department of Economics and Management
}

\begin{abstract}
This paper studies the context and textual structure of the Portuguese translation of Forbonnais's Elémens du commerce (1754). This analysis is instrumental to understanding the place of this translation in the Portuguese discourse on trade, colonies and political economy in the age of Pombal. Forbonnais's translation was one amongst the few published in Portugal in the $18^{\text {th }}$ century. So, why translating it? This paper answers this question by profiling the translator, a key figure in the nomenklatura created by Pombal to promote his commercial and colonial policies. This translation aimed at providing a theoretical background to Pombal's action in defending Portuguese specialised agriculture against the exploitation of British traders, substituting imported manufactures with local production, and putting colonial trade under national control. The paper also studies the contemporary debate on translation and its method, in order to understand the reasons that led the translator to adopt a 'paraphrastic style', a choice that equalled translation to a nationalistic politico-economic act, consisting in importing alien contents as 'raw materials', and 'reselling' them rephrased in what was considered the most ancient and perfect neo-Latin language. In this way, this paper also contributes to the history of translation in the Lusophone area.
\end{abstract}

Keywords: Véron de Forbonnais; translation; $18^{\text {th }}$ century; commerce; colonies; Portugal.

\section{Introduction}

This paper aims to study the Portuguese translation of Véron de Forbonnais's Elémens du commerce, published by José Manuel Ribeiro Pereira in $1766^{2}$ and dedicated to the Marquis of Pombal. This publication was one amongst the few translations of European economic literature that were published in Portugal in the $18^{\text {th }}$-century. ${ }^{3}$ The aims of our investigation are briefly

*m.lupetti@rom.unipi.it; m.guidi@unipi.it.

The design of the paper, the introduction and the conclusions are common to both authors. However, Marco Guidi wrote sections 2 and 3, and Monica Lupetti sections 4 and 5.

2 Elementos do Commercio, traduzidos livremente do francez para o Portuguez pelo mesmo traductor de Telemaco, e das Orações Funebres, 2 vols (Lisboa, 1766). Inocêncio da Silva (Diccionario Bibliographico Portuguez , V, 10, Lisboa, 1860), indicates 1767 as a date of publication. It is probably one of his frequent misprints.

3 The lists provided by António A. Gonçalves Rodrigues, A Tradução em Portugal ... de 1495 a 1950 (Lisboa, 1992) integrated with the Porbase online catalogue (http://porbase.bnportugal.pt/ [accessed on 15 ${ }^{\text {th }}$ Feb. 2014]) - reveal, especially for the first half of the $18^{\text {th }}$ century, a very large predominance of religious works, followed by literature (especially from Latin), history, education, morality and good manners, medicine, discoveries. The domain of politics is largely composed of publications related to contemporary wars: manifestos, declarations of war, descriptions of campaigns and battles, treaties of peace and alliance, and of trade and navigation. The only translations of economic works published after 1750 are Jacques-Nicolas Moreau's O Observador Hollandez ou Primeira Carta de Mons. Van *** a Mons. H. *** de Haya sobre o Estado Presente des Negocios da Europa (Lisboa, 1757-1758); Claude-Jacques Herbert's Prova sobre a policia geral dos trigos, sobre os seus preços e sobre os effeitos da agricultura (Bruxellas, 1766); Pedro Rodríguez Campomanes' Discurso acerca do Modo de Fomentar a Industria do Povo (Lisboa, 1778); and Id., 'Discurso sobre a Educação Popular dos Artistas e seu Fomento, traduzida do Hespanhol por F. R. I. L. E. L. [Francisco Rolland]', in Miscelanea Curiosa e Proveitosa: ou Compilação tirada das melhores Obras das Nações Estrangeiras, traduzida e ordenada por *** C.I. IV (1782), 132-70, 6 (1784), 44-84; 7 (1785), 59-148. To this we can add a handful of treatises of agriculture: Elie Bertrand 
summarised in the abstract. This paper is complementary to the one by Cardeira, Silvestre and Villalva, which studies Forbonnais's translation from a lexicologic viewpoint.

\section{The Resistible Rise of José Manuel Ribeiro Pereira}

José Manuel Ribeiro Pereira, the translator of Elémens du commerce, was a bacharel [graduate] in Law at the University of Coimbra. We ignore Pereira's date of birth, and we know very little about his early career. But we know he had a taste for letters, as he sought glory by publishing in a short delay three translations of celebrated French works: Esprit Fléchier's Oraisons funèbres; ${ }^{4}$ François Fénelon's Aventures de Télémaque; ${ }^{5}$ and Forbonnais. At the same time, he obtained from the Desembargo do Paço, one of the supreme tribunals of the kingdom, the qualification for occupying one of the 'lugares de letras', i.e. those administrative and legal offices (provedores, corregedores, juizes de fora) at local community level (respectively, provinces, comarcas, and conchelhos) that depended on the Crown and extended its control over the periphery of the kingdom. ${ }^{6}$

The texts translated by Pereira were not chosen at random. They were meant to back up the translator's ambitions to occupy a place of eminence in the political elite, by presenting him as an importer of sound moral, political and economic ideas from France. By the beginning of the $18^{\text {th }}$ century France, together with Britain and, to a lesser extent, Italy and Germany, had definitively replaced Spain as a cultural and political influence for the Portuguese elite. Furthermore, under the reign of João V (1706-1750), and even more decidedly under his successor, D. José (1750-1777), when Sebastião José de Carvalho e Melo, the future marquis of Pombal, became the most powerful figure in the Portuguese government, the lead of the reforming movement was taken by the socalled estrangeirados, those Portuguese 'young Turks' who had studied abroad or had sojourned in the main European capitals as diplomats or tradesmen, and aspired to apply to Portugal the successful novelties they had observed during their peregrinations. ${ }^{7}$ Without being one of them, Pereira rode the wave of the moment by offering the translations of some selected masterpieces of European literature. Pereira's translations endeavoured to present French politics and culture as a model that Portugal had to imitate if it wished to recover from decadencia and fill the gap that separated it from the most advanced monarchies of Europe. But-similarly to the majority of his contemporaries - it was the France of the Grand Siècle, of the magnificent reign of Louis XIV, which Pereira purported to make available in the native language of his fellow countrymen, much more than the France of the Enlightenment: the France of politesse, of great literary achievements,

and Fortunato Bartolomeo De Felice, Elementos da Policia Geral de hum Estado, 2 vols (Lisboa, 1786-1787); Leopold Berchtold, Ensaio sobre a extensão dos limites da beneficencia a respeito, assim dos homens, como dos mesmos animaes (Lisboa, 1793); and the mysterious translation of Benjamin Franklin's Poor Richard's Almanak (Meio facil de pagar os tributos, ou Sciencia do bom homem Ricardo, announced in Mercurio Historico, March (1796), 107. According to the list published by Rodrigues, the total number of translations published in Portugal in the $18^{\text {th }}$ century amounts to 1890 . Therefore the share of economics is negligible.

4 Compendio das Orasoens Funebres de Mr Flexier, Bispo de Nymes, vertidas de Fransez em Portuguez, por Jozé Manoel Ribeiro Pereira, bacharel formado na Faculdade de Leis, dadas a Luz por Manoel Rodrigues da Silva (Lisboa, 1764). See Oraisons funèbres composées par M. Fléchier, $2^{\mathrm{e}}$ édition (Paris, 1691).

5 Aventuras de Telemaco, Filho de Ulysses, traduzido do original francez na lingua portugueza, 2 vols (Lisboa, 1765); 2nd edn, 1780(?) The name of the translator does not appear in the book. However, Pereira's authorship was known, as a few years later Manuel de Sousa, in the preface to his new translation ('Prologo do traductor', in $O$ Telémaco de Monsieur Francisco de Salignac de la Motte Fenelon, 2 vols (Lisboa, 1770), [not numbered]; 2nd edn, Lisboa, 1776), mentions him explicitly. See Fernando Alves Cristovão, 'Presença de Fénelon no Espaço Literário LusoBrasileiro. Subsídios para um Estudo’, in Les rapports culturels entre le Portugal et la France (Paris, 1983), 135-50 (136-37).

6 Arquivo Nacional da Torre do Tombo, Lisbon (hereinafter ANTT), Companhia Geral de Grão Pará, e Maranhão (hereinafter Companhia), Livro 87 (Livro de Registo de Consultas), f. 58. See A.H. de Oliveira Marques, História de Portugal, 3 vols (Lisboa, 1997), II, 312-15; R. Ramos (ed.), B. Vasconcelos e Sousa, and N. Gonçalo Monteiro, História de Portugal, $7^{\text {th }}$ edn (Lisboa, 2012), 401.

7 Marques, História de Portugal, 334-38. 
and above all the France of the wise and paternal government of a powerful absolute monarch and of his enlightened counsellors. It was maybe an idealised France, or more exactly a France that had represented at one and the same time a model of monarchical power, and the source for a political culture centred on the ideal of an absolute, enlightened and Christian monarchy, and of an exact and well-managed police.

In choosing to translate this trio, Pereira proved to be an acute observer of the cultural and political climate of the age of Pombal, and was very close to the political strategy of the then-Conde de Oeiras. As Nuno Monteiro has recently written:

Pombal, a contemporary of the Enlightenment, shared with the latter some enemies - the Jesuits and the civil power of the Church - and looked at it for some influences, turning his mind not to the great French intellectuals of the time, but to the southern tendencies that have been defined as 'Catholic Enlightenment'. But he was not a son of the Enlightenment. It was not a hazard if he-like many of his contemporaries - compared himself to Cardinal Richelieu. To a large extent, he was an emulator of the reforming ministers or favourites of the $17^{\text {th }}$ century. And much of what he did was decided as a function of circumstances. ${ }^{8}$

The first translation published by Pereira was the Compendio das Orasoens Funebres de Mr Flexier (1864), a Portuguese abridged version of Esprit Fléchier's Oraisons funèbres (1691). As argued by Sainte-Beuve in the $19^{\text {th }}$ century, Fléchier suffered in France from an 'overwhelming comparison with Bossuet', the great orator and historian who had been his contemporary and whose style was considered paradigmatic. ${ }^{9}$ Apparently this was not the case with Portugal, where-as shown by table 1-not only Fléchier was read and translated more than Bossuet, but his success was independent from, and largely preceding that of, Bossuet. ${ }^{10}$ Significantly, the only translation that preceded those of Fléchier was that of the Exposition de la doctrine de l'Eglise catholique (Paris, 1671), which was written to convince M. de Turenne to embrace the Roman Catholic faith. ${ }^{11}$

Table 1. Portuguese translations of works by Bossuet and Fléchier in the $18^{\text {th }}$ century

\begin{tabular}{|c|c|c|c|}
\hline Year & Bossuet & Fléchier & Translator \\
\hline 1756 & $\begin{array}{l}\text { Exposição da Doutrina da Igreja } \\
\text { Catholica }\end{array}$ & & \\
\hline 1763 & & Exercicio Devoto & $\begin{array}{crr}\text { Paulo Germano } & {[\mathrm{P} .} \\
\text { Tomaz } & \text { José } & \text { de } \\
\text { Aquino] } & & \end{array}$ \\
\hline 1764 & & $\begin{array}{l}\text { Compendio das } \quad \text { Orasoens } \\
\text { Funebres }\end{array}$ & $\begin{array}{l}\text { José Manuel Ribeiro } \\
\text { Pereira }\end{array}$ \\
\hline 1765 & & Panegiricos, e Outros Sermões & Francisco de Sá Sarmento \\
\hline 1768 & & Historia de Teodósio o Grande & $\underset{\text { (captain) }}{\text { Manuel de }}$ Sousa \\
\hline 1768 & $\begin{array}{l}\text { Expozição da doutrina da Igreja } \\
\text { Catholica }\end{array}$ & & $\begin{array}{c}\text { José Caietano } \\
\text { Mesquita }\end{array}$ \\
\hline 1772 & & Panegyricos & $\begin{array}{l}\text { Manuel da Avé Maria } \\
\text { (father) }\end{array}$ \\
\hline 1772 & $\begin{array}{l}\text { Discurso sobre a História } \\
\text { Universal }\end{array}$ & & \\
\hline
\end{tabular}

Ramos (ed.), História de Portugal, 375.

Charles-Augustin De Sainte-Beuve, Les grands écrivains français (Paris, 1928), 153.

10 Portuguese libraries possess many French exemplars of orations by both Fléchier and Bossuet (very often published jointly), which shows that their works largely circulated in the country even independently from translations.

11 Jacques-Bénigne Bossuet, Exposição da Doutrina da Igreja Catholica sobre as Materias de Controversia (Coimbra, 1756). See Oraisons funèbres de Fléchier (Paris, 1826), 108. 


\begin{tabular}{|c|c|c|c|c|}
\hline 1776 & Manual Cristão & & \multicolumn{2}{|c|}{ Matteus Januário Ribeiro } \\
\hline 1786 & & Historia de Theodosio o Grande & $\underset{\text { (captain) }}{\text { Manuel de }}$ & Sousa \\
\hline 1794 & Elevações a Deus & & & \\
\hline
\end{tabular}

Among the translators of Fléchier's works there was captain Manuel de Sousa, an engineer of the Royal Army and member of the Arcadia Lusitana who translated Fénelon and Molière and was probably the author of one of the earliest French-Portuguese dictionaries, published anonymously in $1769 .{ }^{12}$

As reported in the front page, Pereira's translation of Fléchier's Oraisons funèbres was edited ('dadas a luz') by a certain 'Manoel [or Manuel] Rodrigues da Silva' whose identity is uncertain, although the licenses by the Roman Inquisition and by the Ordinary Censorship consider him to be responsible for this edition. However the short preface (Advertensia) is most probably the work of Pereira, as it contains some arguments that will be repeated in the prefaces of other translations.

The Advertensia does not clarify the reasons that brought Pereira to translate Fléchier's orations. He only justifies his choice by 'a esperansa da utilitade publica' [the hope of public utility], and by arguing that the aim of oratory "nam deve ser o lizongear os ouvidos com armoniozos sons, e ocupar a imaginasam com imagens mais brilhantes que solidas; mas sim o comover os corasoens, e intimar a verdade despida de exagerados encomios, e só ornada de pensamentos puros ${ }^{13}$. However, Fléchier's funeral orations, rather than literary exercises or religious meditations, were public speeches, focusing on men and women who had played key roles in French public life during the reign of Louis XIV. In his Eloge de Fléchier d'Alembert defined the great orator as an 'organe de la douleur publique' [spokesman of public sorrow]. ${ }^{14}$ Maybe Fléchier's most famous oration was read on the death of Henri de la Tour d'Auvergne, viscount of Turenne. Its theme was the military and political virtue of this national hero, leader of many fortunate campaigns, who died on the battlefield. Turenne is presented as a wise, loyal and relentless executor of the paternal aims of the king in peace and in war. He defends the country to promote the security and well-being of his countrymen, in the name of the sovereign. His 'civil virtues' in peace are moderation, modesty and frugality. His conversion from Calvinism to Catholicism made him an example of Christian pure faith. All the personages masterly depicted by Fléchier are ' $\mathrm{m}[\mathrm{e}] \mathrm{n}$ of the king', ${ }^{15}$ who work to promote the aims of government: welfare, military power, justice, charity, and religious orthodoxy.

The life of Fléchier and that of Fénelon are connected by various threads. It is known that on the

12 Dictionnaire françois, et portugais plus complet que tous ceux qui ont paru jusqu' a present pour l'instruction de la jeunesse portugaise (Lisbonne, 1769).This dictionary is not recorded in T. Verdelho, 'Lexicografia Portuguesa Bilingue. Breve Conspecto Diacrónico', in Lexicografia Bilingue. A Tradição Dicionarística Português - Linguas Modernas, edited by Telmo Verdelho and João Paulo Silvestre (Lisboa and Aveiro, 2011), 13-67 (20-23), among the earliest Portuguese-French dictionaries published in Portugal in the second half of the $18^{\text {th }}$ century. The title of the second edition of this dictionary (Nouveau dictionnaire François-Portugais, composé par le capitaine Emmanuel de Sousa, \& mis en ordre, rédigé, revî, corrigé, augmenté, \& enrichi de tous les termes techniques, \& propres des sciences, des arts, des métiers, de géographe; \&c..., par Joachim Joseph da Costa e Sá..., 2 vols, Lisbonne, 17841786 ) is the source from which we base the attribution of the first anonymous edition to Sousa. According to the information provided by Verdelho, Sousa's dictionary is the second in its genre ever published in Portugal. See Marques, História de Portugal, 338.

13 '...should not be to flatter ears with harmonious sounds, and occupy the imagination with bright rather than solid images. It should move hearts, and insinuate the truth out of any exaggerated eulogy, and only embellished with pure thoughts', Compendio das Orasoens Funebres, [1].

14 d'Alembert in Fléchier, Oraisons funèbres (1826), 3.

15 Fléchier, Oraisons funèbres, 256. 
death of Fléchier, Fénelon declared: 'Nous avons perdu notre maître'. ${ }^{16}$ Amongst the funeral orations Fléchier delivered there was that on the duc de Montausier ${ }^{17}$ chief-tutor of the Grand Dauphin, Louis XIV's son, an office he shared with Bossuet and Huet. And Fénelon was the tutor of the duc de Bourgogne, Louis XIV's grand-son, for whom he wrote the Télémaque. All this is not mentioned as a simple matter of curiosity: the point is that Pereira's translations intended to introduce to a Portuguese readership the works of two counsellors of the Prince who had won renown for Louis-le-Grand's court thanks to their intellectual merits and moral examples. These counsellors had taught the future kings how to govern their country for the good of their subjects, and Pereira indirectly presented himself as a potential counsellor of sua majestade fidelíssima etymologically as a trans-lator of the best political culture expressed by late $17^{\text {th }}$-century France.

There was however an important difference between Fléchier and Fénelon-a difference that was possibly less acutely perceived in the mid- $18^{\text {th }}$ century than sixty years earlier: Fléchier, like Bossuet, had been a convinced apologist of Louis XIV's politics, whereas Fénelon was famously accused by Bossuet himself for his alleged criticism of Louis-le-Grand's tyrannical interpretation of the role of an absolute monarch. Fénelon's political disgrace was a consequence of his ideal of a monarch submitted to law - the law he himself had given, not a constitution-who preferred the prosperity of his subjects to conquest and personal glory, and accepted the spiritual guide of the Church. ${ }^{18}$ But even in France the fame of Fénelon had changed in the 1760s, and now Télémaque was considered a masterpiece in the literature on the Prince's education. What counted for Pereira was that both Fléchier and Fénelon had depicted absolute monarchy as the most perfect government, and a moral and enlightened sovereign as the true artisan of peace, opulence and justice.

But why did Pereira decide to translate the Télémaque? The three introductory pages ('A Quem Ler') to the translation do not provide very useful information. Pereira addressed his work 'aos meos patricios que se naõ tiverem applicado ao estudo da lingua Franceza' [to my fellow countrymen who did not apply themselves to the study of the French language]. ${ }^{19}$ He rhetorically argued that Fénelon's fame exempted hum from defending the utility of this translation. The fact that Télémaque had already been translated into many languages was a sufficient guarantee of its quality. But the political message of Fénelon's novel was too evident to go unnoticed. Objectively, translating Télémaque implied presenting an idea of political and economic reform of Portugal based on the models of virtuous government proposed by Fénelon in that book. The turn of the screw of censorship that Pombal was introducing in those years ${ }^{20}$ made it prudent to present political ideas in an indirect way, as the literary shape of Télémaque allowed to do.

Télémaque offered a model of enlightened, peaceful and paternal absolute monarchy ${ }^{21}$ grounded on the rule of $\operatorname{law}^{22}$ and on a reform of the traditional social and economic order that aimed to preserve its hierarchies. ${ }^{23}$ Important elements of this strategy were the introduction of frugality and temperance in the habits of all subjects, including the court and the aristocracy. Luxury was seen by Fénelon as a threat of social stability not only because it corrupted the morals of the population, but also because it overturned social hierarchies by allowing the enriched bourgeoisie or the noblesse de robe to appear superior to the most ancient aristocracy 'of the sword' ${ }^{24}$ Such a reform of public morality should be promoted through public education, ${ }^{25}$ since 'les enfants [...] appartiennent moins à leurs parents qu'à la république; ils sont les enfants du peuple; ils en sont l'espérance et la force'. ${ }^{26}$

Such a political programme required a reform of political economy, implying sumptuary laws

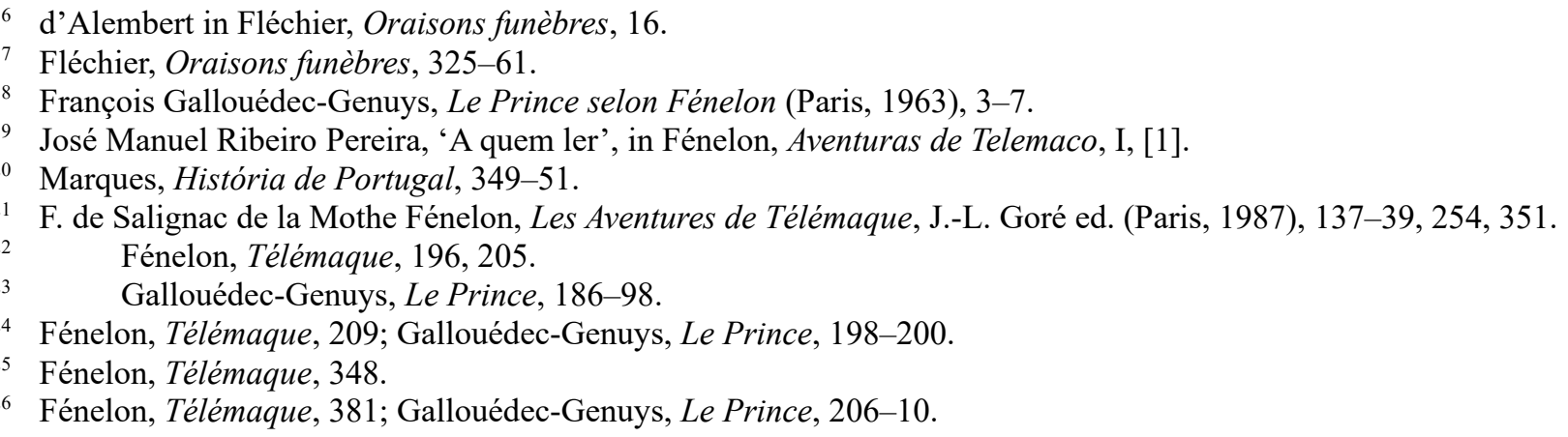


and restrictions on the production and importation of luxury goods. ${ }^{27}$ Preserving social hierarchies implied a reduction of the room for competition and emulation and a subdivision of land proportional to rank, avoiding the concentration of large fortunes. ${ }^{28}$ It also implied basing the economy of the kingdom on an abundant population, ${ }^{29}$ a stable (and stationary) agriculture, ${ }^{30}$ as economic growth led by trade and manufactures could threaten the primacy of landed aristocracy. ${ }^{31}$ Fénelon looked favourably to smallholding not as an incentive to productivity, but as a measure that granted to every honest peasant a modest although safe, healthy and robust existence. ${ }^{32}$ Trade should be equally encouraged but on condition that it was based on the exchange of agricultural goods and aimed to provide the nation with abundant and low-price means of subsistence. ${ }^{33}$ Encouraging trade to promote accumulation and growth was not admitted. But trade should not be stimulated by artificial means and to the detriment of agriculture, as Colbert had attempted to do. Wise kings should just allow ships from any country to make landfall in their harbours, attracting trough free trade the largest possible number of merchants. ${ }^{34}$

This anti-Colbertist message of Fénelon's political economy was clearly conveyed by Pereira's translation. How was it possible that he might decide to promote this idea at the apex success of Pombal's policies aiming at protecting national manufactures, modelled on French manufactures royales, and national trade through navigation acts and artificial monopolies on national and colonial trade $?^{35}$ Was Pereira unaware of the differences between what Fénelon recommended and what Pombal was doing? Did he dare to criticise the Conde de Oeiras? There are two reasonable answers to these questions. The first one is that what counted most for Pereira was to present to Portuguese readers the general thrust of Fénelon's politics and political economy, rather than defending the agriculturist and anti-mercantilist penchant of his theories. From this point of view Télémaque offered the picture of a paternal and pastoral sovereign who actively promoted sobriety, popolousness, a prosperous agriculture and a regular trade. ${ }^{36}$ The second answer is that Télémaque presented the main example of the kingdom of Idomenée in Salente, whose programme of reforms based on an agriculturist model had been dictated by Mentor, but also the example of Tyre, a peaceful and prosperous commercial power. ${ }^{37}$ The point was however that in both cases the regulation of trade, although aimed at avoiding the importation of luxury goods to banish luxury and corruption from national consumption, ${ }^{38}$ did not aim to substitute import with national production, as it had been the case with Colbert and more recently with Pombal. But trade for Fénelon, if it was to be a source of opulence, should be extended as much as possible. And in order for this to be so, it should be free (or more exactly sometimes be subject to moderate import duties, sometimes to no duties, and sometimes even to bounties on exportation). ${ }^{39}$ The aim of free trade was not promoting competition: it was maximising the importation of necessary goods ${ }^{40}$ and the exportation of internal surplus production (vent for surplus), ${ }^{41}$ within a natural division of labour among nations. ${ }^{42} \mathrm{~A}$ restrictive policy based on prohibitions and privileges would limit such an abundant supply of goods. This approach contradicted two times Pombal's policy, both because it run against mercantilist policies, and because it opposed Pombal's protectionist efforts to rescue

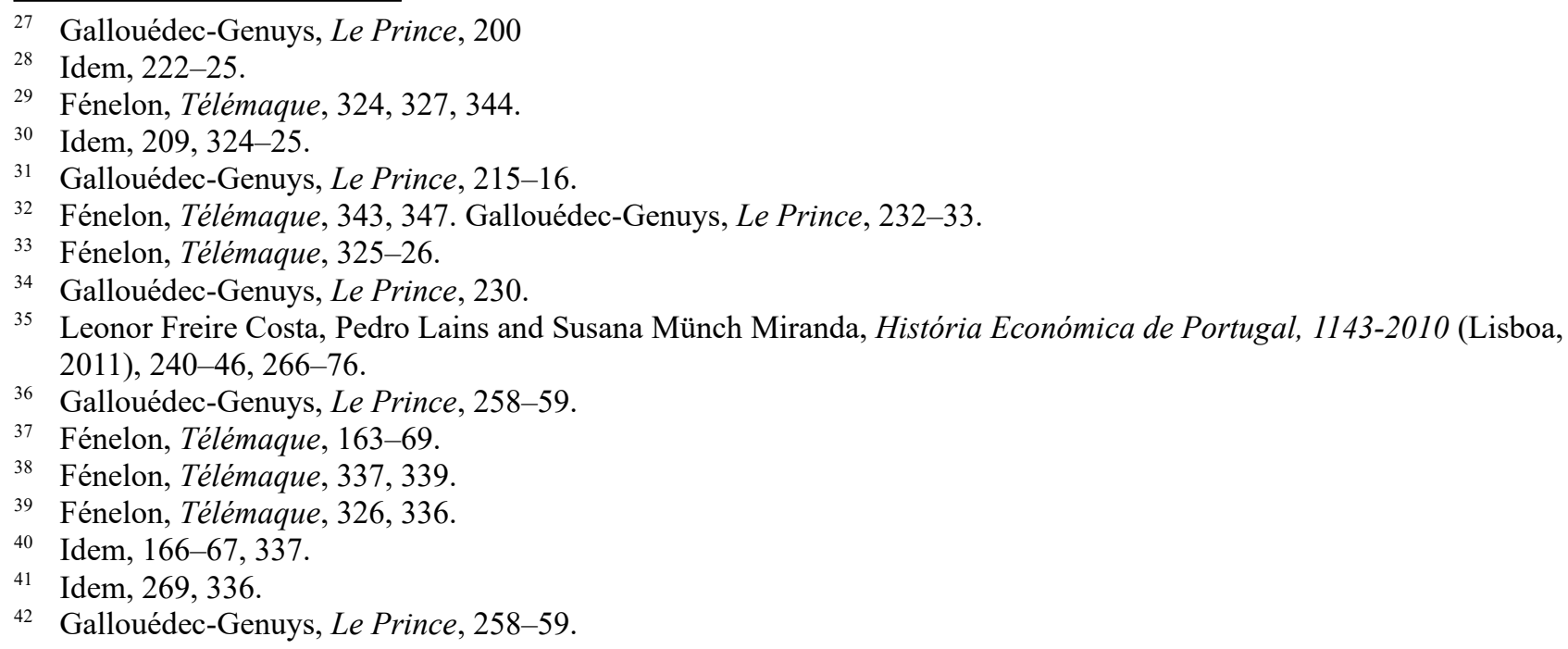


trade from the monopoly of British and French navies. Even the regulation of agriculture suggested to Idomenée contained an element that must displease the Conde de Oeiras. The Télémaque contains various passages against the consumption of wine and spirits, ${ }^{43}$ and Mentor recommends to Idomenée to 'prendre garde à ne laisser jamais le vin devenir trop commun dans votre royaume. Si on a planté trop de vignes, il faut qu'on les arrache: le vin est la source des plus grands maux parmi les peuples; il cause les maladies, les querelles, les séditions, l'oisiveté, le dégoût du travail, le désordre des familles'. ${ }^{44}$ Pereira voiced this argument just a few years after Pombal had created a company - the Companhia das Vinhas do Alto Douro (1756) - to protect the production of Port wine and the distillation of aguardente. ${ }^{45}$

But there was an irony in this story, which at the end absolved Pereira from any suspicion: the censors charged to assess the translation did not perceive these contradictions. The theologist Fr. Joaõ Baptista de São Caetano, an enlightened monk of Saint Benedict who actively promoted the importation of contemporary French and Italian philosophy and theology, ${ }^{46}$ acted as censor for the Roman Inquisition. In his Licensa, he simply echoed the high reputation enjoyed by Fénelon in mid- $18^{\text {th }}$-century Europe ${ }^{47}$ to recommend the publication of Pereira's translation. Fr. Joseph da Madre de Deus, the episcopal censor (do Ordinario), found no contradiction between the work, Catholic dogmas and Christian ethical principles. ${ }^{48}$ But it was the royal censor (do Desembargo do Paço), Manuel de Macedo Pereira de Vasconcelos, ${ }^{49}$ who sanctioned the political orthodoxy of Fénelon's novel. Vasconcelos clearly highlighted that the main message of Télémaque lay in the vision of a wise king who takes a paternal care of the welfare of his subjects. ${ }^{50}$ And he went on by arguing that the political economy described by Fénelon was exactly that of Portugal under the reign of D. José, i.e. under the government of Pombal: a mercantilist and industrialist policy.

Sim, Senhor, he do juizo delicado de Vossa Magestade, como do cerebro de Minerva, que perennemente dimmanam as meravilhozas rezoluçoens, com que a destra, e infatigavel mam de Vossa Magestade, mam verdadeiramente real, arranca os abuzos mais inveterados, prommove a reforma dos estudos, adianta o commercio, faz florecer as fabricas mais uteis, conserva, e aperfeiçoa a disciplina militar das Tropas ... honra o merecimento aonde quer que o acha, naõ o apparente, mas o solido. Feliz Portugal! ${ }^{51}$

The rhetorical overtones of this texts and its unusual length reveal that Vasconcellos was not unaware of the risks of publishing a text that under a literary veil dictated the guidelines of

43 Fénelon, Télémaque, 195-96, 267-68.

44 Idem, 347-48.

45 Costa et al., História Económica de Portugal, 228-29.

46 See Luis A. de Oliveira Ramos, 'Pombal e a Reforma dos Estudios Monásticos (o Caso Beneditino)', Revista de História das Ideias, IV-2 (1982), 113-24 (116-17).

47 Joaõ Baptista de São Caetano, in [Fénelon], Aventuras de Telemaco, [not numbered].

48 Joseph da Madre de Deus, in [Fénelon], Aventuras de Telemaco, [not numbered].

49 He was probably a former Oratorian Father who in 1760 or 1761 became a secular priest and taught Rhetoric and Poetry in the of Nossa Senhora das Necessidades in Lisbon. See Francisco Topa, 'Seis Poemas Inéditos do Brasileiro Manuel de Macedo Pereira de Vasconcelos', Revista da Faculdade de Letras - Línguas e Literaturas, 2 nd series, 21 (2004), 303-13.

50 [Fénelon], Aventuras de Telemaco, [not numbered]: 'Como he possivel que Vossa Magestade negue a hum livro a licensa que pede para se imprimir, se a moral, que ensina, se as maximas, que establece sam totalmente conformes aos sabios dictames que Vossa Magestade pratîca no seu felicissimo governo? Minerva disfarsada na figura do velho Mentor toma á sua conta instruir ao filho de Ulysses na grande arte de reinar. He com a assistencia particular daquella Deoza que Telemaco, superior á sua idade tenra, se monstra sempre, intrepido nos perigos, constante nos trabalhos, zeloso, e exacto na fiel administraçaõ da justiça, próvido, diligente, incansavel. Como se nascere unicamente para o bem dos povos, de que havia ser pay carinhozo, mais que Monarca absoluto, consagra todos os preciozos momentos da sua vida á utilidade publica'.

51 'Yes, Sir, it is from the acute judgement of Your Majesty, like from the mind of Minerva, that perennially follow the marvellous resolutions through which the right and relentless hand of Your Majesty, a truly royal hand, tears away the most inveterate abuses, promotes the reform of studies, advances trade, makes the most useful manufactures to flourish, preserves and improves the military discipline of the Troops [...] honours merit wherever he believes to discover it: not apparent merit, the true one only. Oh joyous Portugal!'; see Vasconcelos in [Fénelon], Aventuras de Telemaco, I [not numbered]. 
economic policy. His aim was to show that, despite differences in approach that it was prudent to pass under silence, the spirit of fomento was the same for both Mentor and Pombal.

Significantly, the second translation of Télémaque, published by Manuel de Sousa in 1770, was dedicated 'ao Ill. ${ }^{\text {mo }}$, e Ex. ${ }^{\text {mo }}$ Senhor Marquez Secretario de Estado', in the very year in which Pombal obtained the title by which he is universally known. Sousa adopted a similar argumentative strategy by arguing that Télémaque was 'huma obra, cujas maximas sem precisar estudalas, descubrio V. EXCELLENCIA á força de aturada meditaçaõ, poz em pratica desde o berço a sua bem formada indole, e confirmou depois o seu acertado raciocinio'. ${ }^{52}$

The third translation published by Pereira in 1766 presented to the Portuguese public an adaptation of Elémens du commerce. We will examine the characteristic of this translation in a separate section. However it is worth mentioning here that the way in which it was packaged reveals once again the author's intention to gain the confidence of the Secretary of State's entourage. As revealed by the dedicatory letter addressed to the future Marquis of Pombal, Pereira who defines himself as 'hum homem [...] muito amante das fortunas da sua Patria' [A man who is fond of the fortune of his homeland $]^{53}$ - looks at his own work as a sympathetic contribution to the policies adopted by the Conde de Oeiras to stimulate manufactures and trade. The dedication purposely provides the following informed and accurate picture of Pombal's action eleven years after his rise as 'prime minister' of King José:

Deve de justiça dedicar-se a V. EXCELLENCIA, hum tratado, que estabelece principios ao Commercio, e augmentos á felicidade publica; pois o Commercio nestes Reinos deve a V. EXCELLENCIA a protecçaõ, e a felicidade publica sempre lhe deverá agradecimentos.

E na verdade, Senhor, naõ he V. EXCELLENCIA aquelle incomparavel Eroé, que sabiamente illustra as maximas mercantís deste escritor preclaro, e que as sabe fazer praticar, e proporcionar igualmente que elle as soube escrever? Naõ he ao zello incansavel de V. EXCELLENCIA, que esta Monarchia venturoza deve os augmentos que consegue, e os progressos com que se vai distinguindo entre as naçoens? Que vantajes naõ estaõ respirando as Fabricas, a Agricultura, e o Commercio? Que abundantes felicidades naõ estaõ prometendo a nossos compatriotas, as altas idéas que para bem universal do Reino, continuamente occupaõ a illuminada comprençaõ de V. EXCELLENCIA.

Por maons de V. EXCELLENCIA, he que o nosso AUGUSTISSIMO MONARCHA dirige aquellas sabias determinaçoens, que saõ a fonte de toda a ventura que logramos. Huma lei que erige Fabricas; outra que anima os artistas com privillegios. Huma que protege companhias mercantís; outra que estabelece juntas que derijaõ regularmente o Commercio, e o bem commum dos vassallos. Huma que funda aulas para a mocidade o aprender; outra que edifica collegios para a nobreza se instruir. Huma que prescreve formas á navegaçaõ; outra que arranca os abusos da Agricultura. Aquella que seguindo os dictames puros da razaõ, poem n'huma ordem seria as ultimas dispoziçoens da vida; esta que attendendo á maior oppolencia do Estado, faz aparecer de novo no Commercio hum bem consideravel fundo de

52 '...a work, whose maxims YOUR EXCELLENCY discovered without needing to study, by constantly and strenuously meditating them. His well educated character practiced them since the cradle, and his well adjusted reason subsequently confirmed them'; see Manuel de Sousa, in Fénelon, O Telémaco, [not numbered]. Two further translations were published in 1785 by the Tipografia Rollandiana, and in 1788 by Joaquim Joseph Caetano Pereira e Sousa, a lawyer of the Casa da Suplicaçaõ. The latter was an original translation in verse. The book was dedicated to the Prince of Brazil, D. José. Prince José died at the end of that very year, disappointing the hopes of those who looked at him for a regeneration of the Portuguese government. See Ramos (ed.), História de Portugal, 429. There was also an interesting imitation of Télémaque entitled Aventuras de Diófanes, Imitando o Sapientissimo Fenelon na sua Viagem de Telemaco, published by Teresa Margarida da Silva e Orta (1712-1793) under the anagrampseudonym of Dorothea Engrassia Tavareda Dalmira (Lisboa, 1777). The first edition of this novel was published in 1752 under a different title (Maximas de virtude e formosura, come que Diofanes, Clymenea e Hemirena, principes de Thebas, venceram os mais apertados lanches da desgraça). This novel is considered at the same time the first Portuguese feminist novel and, with some exaggeration, the first Brazilian novel. See Rui Bloem, 'Teresa Margarida e o Romance Brasileiro', in Teresa Margarida da Silva e Horta, Aventuras de Diófanes (Rio de Janeiro, 1945), v-xvi. It enjoyed a certain popularity in the $18^{\text {th }}$ century, going through three editions, and early $19^{\text {th }}$ century (one edition in 1818). Two less problematic further works by Fénelon were translated into Portuguese in the $18^{\text {th }}$ century: the Dialogos sobre a Eloquencia em Geral e a do Pulpito em Particular (Lisbon, 1761), a work that, as declared in the translator's preface, was addressed to the Clergy, and the Dialogos dos Mortos (Lisbon, 1786).

53 [Forbonnais], Elementos do Commercio, [9]. 
riqueza capaz de girar nelle como moeda. ${ }^{54}$

Clearly Pereira was convinced that the translation of this text, which, as we shall see, he attributed to Montesquieu, was a service rendered to Pombal and a proof of his own commitment to the reforming strategies of the Conde de Oeiras.

Be it as it may, two years later, on $5^{\text {th }}$ March 1768, José Manuel Ribeiro Pereira was appointed secretary of the Junta da Administração (Managing Board) of the Companhia Geral do Grão Pará, e Maranhão, one of the chartered trade companies that had been created by the future Marquis in 1755 (some months before the famous earthquake), to 'nationalise' the commercial relations of Portugal with the colonies of Brazil (the other being the Companhia Geral de Pernambuco $e$ Paraiba, est. 1756). ${ }^{55}$ Pereira replaced the former secretary Antonio Domingues do Passo, who had resigned some time earlier. ${ }^{56}$ The appointment was to be confirmed every three years, and Pereira should also perform the role of 'Juiz de Fóra de primeira entrancia' for the Company. ${ }^{57}$ Pereira's service should be counted as a service in the Lugares the Letras (offices appointed by the king), role for which, as mentioned above, he had been qualified by the Desembargo do Paço. ${ }^{58}$

The nomination was approved by the king on $17^{\text {th }}$ March, and Pereira took service on $26^{\text {th }}$ March. ${ }^{59}$ A report on the internal organisation of the company requested by the Secretary of State in December 1756, one year after the establishment of the Company, extensively describes the role of the Secretary. ${ }^{60}$ The Junta met every Monday, Wednesday and Friday, and all members had an obligation to attend, absence being sanctioned with appropriate fines. ${ }^{61}$ The superintendent (provedor) sat on one side of the table and the Secretary on the opposite side, while other counsellors (deputados) freely chose their seats. Each decision was discussed in depth, with a view

54 'With justice Your Excellency must be the addressee of a treatise, which establishes the principles of Commerce, and increases public happiness: for Commerce in these Kingdoms is owed to Your Excellency's protection, and public happiness should always be grateful to Him.

And indeed, My Lord, is not Your Excellency that incomparable hero, who wisely illustrates the mercantile maxims of this eminent writer, and knows how to practice them, and to manage them in the same way in which he was able to write them? Is it not to the untiring zeal of Your Excellency that this blissful Monarchy owes the growth it has attained, and the progresses through which it is distinguishing itself among nations? What advantages are Manufactures, Agriculture, and Commerce not enjoying? What abundant happiness is not promised to our countrymen by the high and universal ideas that, for the universal good of the Kingdom, continually occupy the enlightened mind of Your Excellency.

By the hands of Your Excellency, our August Monarch orders those wise resolutions, which are the source of all the fortune we are achieving. A law that erects Factories and another that encourages artists with privileges. Another that protects commercial companies; and another that establishes boards which constantly regulate Commerce, and the common good of the subjects. A law founding classes for youth to learn trade, and another that erects schools for the education of the nobility. A law prescribing rules for navigation; another extirpating abuses from Agriculture. One that, following the pure dictates of reason, puts a serious order to the latest provisions of life; another that, with a view to the greatest opulence of the State, brings up again into Commerce a considerable fund of wealth which can circulate in it as money...'; see Pereira, in [Forbonnais], Elementos do Commercio, [6-9].

55 Costa et al., História Económica de Portugal, 268-76. See also José Mendes da Cunha Saraiva, Companhia Geral de Pernambuco e Paraiba (Lisboa, 1941); Francisco D.F.C. Trancoso, Os Arquivos das Companhias Gerais do Grão-Pará e Maranhão e de Pernambuco e Paraíba (Lisboa, 1947); António Carreira, As Companhias Pombalinas: de Grão-Pará e Maranhão e Pernambuco e Paraíba (Lisboa, 1983); A Companhia Geral do Grão-Pará e Maranhão (São Paulo, 1988); Rui de Figueiredo Marcos, As Companhias Pombalinas: Contributo para a História das Sociedades por Acções em Portugal (Coimbra, 1997).

56 ANTT, Companhia, Livro 87 (Livro de Registo de Consultas), f. 58 ('Sobre haver S. Mag.de por bem confirmar a nomeaçaõ que a Junta tem feito do Bacharel Joseph Manoel Ribeiro Pereira para Secretario da mesma Junta').

57 ANTT, Companhia, Livro 87, f. 58. A juiz de fora was a magistrate nominated by the king normally to represent him in concelhos, where an independent judge was required to assess legal controversies in an impartial way. The Company, as a special jurisdiction, was provided with a similar figure. A juiz de primeira entrância (or instância) was a trial judge (or judge in a court of first instance).

58 ANTT, Companhia, Livro 87, f. 58.

59 ANTT, Companhia, Livro 89 (Livro de Registo das Procurações e Provimentos), f. 3v.

60 ANTT, Companhia, Livro 87 (Livro de Registo de Consultas), ff. 10-14 ('Rezoluçaõ, Belem, 15 de Dezembro de 1756'). Pombal requested this report to provide a model for the establishment of the Companhia Geral de Agricoltura das Vindas do Alto Douro.

61 ANTT, Companhia, Livro 87 (Livro de Registo de Consultas), f. 11r. 
to reaching unanimity. Majority vote was an exception, ${ }^{62}$ and in this case it was the secretary who collected the votes cast by the counsellors. ${ }^{63}$ The provedor and deputados were remunerated with a commission of 6 percent on sales, while other employees, including the secretary, the juiz conservador and the procurador fiscal, received a salary paid in quarters. ${ }^{64}$ The secretary also presided over the oath of new provedores and deputados. ${ }^{65}$

The registers of the Company record the omnipresent role of Pereira, who signed official documents, contracts, accounts, etc. ${ }^{66} \mathrm{He}$ cooperated to the main activities of the Company, including the encouragement of the agriculture of northern Brazil through credit and other means, the trade of colonial products (cocoa, coffee, cotton, rice, and leather), ${ }^{67}$ the sale of Portuguese products in the Brazilian market (not only wine, but a series of manufactured goods) ${ }^{68}$ the slave trade between the coast of Guinea and Brazil, ${ }^{69}$ and the civil and military administration of the imperial territories. ${ }^{70}$ Pereira was repeatedly confirmed in his office,$^{71}$ until the extinction of the Company decreed by Queen Maria I in 1778, shortly after her accession and the dismissal of Pombal.

Even after the extinction of the Company, Pereira remained in his place to manage its liquidation (in this form the Company survived well after the mid- $19^{\text {th }}$ century). In the framework of the socalled viradeira [turn], Dona Maria overturned the policy of titles adopted by Pombal, who had virtually suspended them to to put a stop to the unlimited power of the aristocracy. Not only did she grant or restore in a few months a large number of titles and orders to the benefit of the major aristocratic houses, but she extended such honours to new categories. One of these titles was the Habito da Ordem de Christo, which had been previously reserved to members of the nobreza civil. ${ }^{72}$ Pereira was one of those who benefited from its extension: on $29^{\text {th }}$ October 1778 the queen awarded him the Habito, with an appended life annuity of 8 reis $20 .^{73}$

We ignore how long Pereira remained in office. The motivation of the mercê mentions that he was expected to serve at least for the next three years. In any case, he had more time to devote to literary activities, as he resumed the old habit of publishing translations from French. The two works he translated have many points in common. To begin with, they belong to two close moralistic genres. The first of them, Eustache Le Noble's Ecole $d u$ monde, ${ }^{74}$ was an example of educational book in the dialogic style, in which a fictitious father named Aristipe instructed his young son Timagene on how to behave in the world. The second work, Edward Young's, The Complaint, or Night Thoughts on Life, Death and Immortality, ${ }^{75}$ which Pereira translated from French ${ }^{76}$ was a meditation in verses on religious and moral issues occasioned by the tragic events

62 ANTT, Companhia, Livro 87 (Livro de Registo de Consultas), f. 11r-v.

63 ANTT, Companhia, Livro 87 (Livro de Registo de Consultas), f. 13v.

64 ANTT, Companhia, Livro 87 (Livro de Registo de Consultas), f. 11v.

65 ANTT, Companhia, Livro 89 (Livro de Registo das Procurações e Provimentos), ff. 4 v-5 r (25 Aug. 1768)

66 See ANTT, Companhia, Livro 89, ff. 4-9; Livro 90 (Livro de Registo de Escrituras), ff. 17-25.; Livro 91 (Registo do Expediente da Contabilidade), f. 5.

67 Costa et al., História Económica de Portugal, 260-61.

68 See ANTT, Companhia, Copiadores 94-99.

69 Costa et al., História Económica de Portugal, 270-71.

70 Ramos (ed.), História de Portugal, 421.

71 See for example ANTT, Companhia, Livro 89, f. 10 (5 Aug 1778).

72 Ramos (ed.), História de Portugal, 406.

73 ANTT, Registo Geral das Mercês, Livro 5, f. 155.

74 Eustache Le Noble, L'École du monde, ou Instruction d'un père à un fils, touchant la manière dont il faut vivre dans le monde (Paris, 1694-1695) (quotes are from the edition of 1700); transl. Escola do Mundo ou instrucção de um pai a seu filho sobre o modo, por que se deve conduzir no mundo, dividido em dialogos, traduzida em portuguez por José Manuel Ribeiro Pereira, 4 vols (Lisboa, 1780).

756 vols (London, 1742-1745).

${ }^{76}$ Les nuits d'Young, traduites de l'anglois par M. Le Tourneur (Paris, 1769); transl. Noites Selectas de Young, traduzidas do inglez em portuguez por Joseph Manoel Ribeiro Pereira, bacharel formado na Faculdade de Leis, actualmente empregado no serviço de Sua Magestade Fidelissima no lugar de Secretario da Companhia do Pará, e Maranhaõ ... traducçaõ augmentada com o Poema do Juizo ultimo do mesmo Author (Lisboa, 1782); 2nd edn (Lisboa, 1783); 3rd edn (Lisboa, 1787). Silva, Diccionario, V, 9, dates the 1st edition from 1781. But we found no trace of such a publication. 
occurred to the author in the last years of his life. These works did not deal with political or politico-economic issues. The only connection we find in them with Pereira's former experience is that in some way they mirror the mindset and lifestyle of a commercial and professional bourgeoisie, although in a conservative framework in which the aristocracy is still considered at the top of social and moral hierarchies. In Le Noble's work, there is a eulogy of the 'man of commerce', whose activity is based on confidence and reputation; ${ }^{77}$ and Young's seventh Night is a discourse on the value of time, which the virtuous man must always treat with 'economy'. ${ }^{78}$

Both works, if not altogether forgotten are not included today in canonical galleries of literary classics. But they were very popular in the first half of the $18^{\text {th }}$ century all over Europe. Le Noble's Ecole was translated into English, German, Italian, Spanish, Portuguese and Polish, while Young's Nights were translated into French, German, Italian, Spanish, Portuguese, Swedish and Hungarian. ${ }^{79}$ In Portugal, before Pereira, Le Noble's dialogues had been already translated by António Blem, ${ }^{80}$ and a catalogue of the booksellers Borel and Rolland of Lisbon announces a new edition in 4 volumes at the end of the $1760 \mathrm{~s}^{81}$ of which however we found no trace. ${ }^{82}$ As to Young, Pereira's translation opened a whole season of popularity for his works. His edition-whose appendix contained the translation of the Poem on the Last Day (Oxford, 1713) - went through two further editions (1783 and 1787). Another translation of Nights, also containing other writings by Young, was published by Vicente Carlos d'Oliveira in 1785, followed by two reprints. ${ }^{83}$ Still in 1785 a short essay was published in an anthology of moral stories ${ }^{84}$ In 1786, Vicente de Oliveira translated The Revenge (London, 1721), ${ }^{85}$ the first of two dramatic works, the second being Busiris (London, 1719), which he translated in $1788 .^{86}$ Finally, in 1790 the satyrical poems entitled The Universal Passion (London, 1728) were translated in Porto under the title of Tratado das Paixoens. ${ }^{87}$

Finally, both works translated by Pereira were products of the $17^{\text {th }}$ century rather than of the age of Enlightenment. Both mirrored a quite conservative and hierarchical social order and put honour rather than liberty and equality at the top of the scale of ethical values. They regarded trade and craftsmanship as useful and legitimate activities, provided that they did not attempt to reverse traditional hierarchies through greediness or corruption. ${ }^{88}$ This was a further element of continuity with Pereira's earlier translations.

So why did Pereira choose to translate these two works? A clue to answering such a question comes from the dedicatory letter prefaced to Young's translation. The book is dedicated to 'João Carlos de Bragança e Ligne de Sousa Tavares Mascarenhas da Silva, 2. ${ }^{\circ}$ Duque de Lafões, 4. ${ }^{\circ}$ Marquês de Arronches and 8. ${ }^{\circ}$ Conde de Miranda do Corvo', who since 1780 had been appointed Presidente perpétuo of the newly founded Academia Real das Ciências (est. 1779). Did Perteira hope to be appointed member of the Academy? It was certainly hard for him to become an ordinary member, as only eight scholars could be included in each of the three classes (Sciences of observation, Sciences of calculation, and Letters). But he could aspire to a place of honorary or supernumerary member, ${ }^{89}$ and he may have thought that his literary attempts were instrumental to

Le Noble, L'École du monde, 56-57.

Noites Selectas de Young, 135-36.

79 This information is based on a search made in the website of KVK - Karlsruher Virtueller Katalog (http://www.ubka.uni-karlsruhe.de/kvk.html), to which we send for the bibliographic details concening these translations.

802 vols (Lisbon, 1722-1724).

81 Published as an appendix of Domingos dos Reis Quita, Obras poeticas (Lisboa, 1766), [189].

82 Silva, Diccionario, V, 10, mentions as a date of Pereira's translation 1781 but there is no trace of a second edition or reprint published in that year.

83 Noites d'Young, addicionada com ... o Triunfo da Religiaõ, e outros opusculos do mesmo Young, 2 vols (Lisboa, 1785); 2nd edn (Lisboa, 1791); 3rd edn (Lisboa, 1804).

84 Edward Young, 'O castigo da prostitução', in Contos Moraes para Entretenimento e Instrucção das Pessoas Curiosas (Porto, 1785), 209-38.

85 Nova Tragedia Intitulada A Vingança, do doutor Young (Lisboa, 1786); 2nd edn, 1788.

86 Nova Tragedia Intitulada Buziris Rey do Egipto, ... composta pelo Doutor Young (Lisboa, 1788).

87 Tratado das Paixoens, composição de Young (Porto, 1790).

${ }_{88}$ Le Noble, Escola do Mundo, 42-46.

89 See Fernando Reis, Academia das Ciências de Lisboa, Instituto Camoes, Ciência em Portugal, Personagens e 
obtaining such an award.

\section{Pereira maintains: 'volume three' of Télémaque}

Only one thing was missing to open to Pereira the door of academic honours, or so he could guess: this was a literary work of his own. In a way Pereira attempted to do something of this kind by writing from bottom to end a 'volume three' appended to the second edition of his translation of Télémaque. ${ }^{90}$ The title of this volume was: Aventuras Finaes de Telemaco, Filho de Ulysses. Inocêncio da Silva reserved to this work an ironical comment: 'a translator's original creation, destined in his opinion to complete Fénelon's work, which in his view lacked a final, not containing the wedding of the hero!'. ${ }^{91}$ This remark probably discouraged readers of the $19^{\text {th }}$ and $20^{\text {th }}$ century from examining such a 'philistine' work.

Inocêncio's comment was largely appropriate for the 'private' parts of this ancestor of Hollywood sequels: the weddings between Telemachus and Antiope, the birth of their two children, Telemaquion and Anaxibéa. However the Aventuras Finaes contained two quite intriguing political parts, which deserve some attention for the present reconstruction of Pereira's political and economic views. Book XXIX ${ }^{92}$ describes the reforms introduced by Ulysses in Ithaca after returning from his peregrination and regaining power over the Suitors of Penelope. And concluding books XXXI and XXXII contain a detailed instruction given by Ulysses to Telemachus on how to make a kingdom strong and happy, after Ulysses' decision to abdicate in order to 'passar o resto [da sua vida] com mais socego, na companhia da sua querida Penelope, por ver se assim tambem vencia o seu destino, e evitava a ser morto por seu proprio filho, conforma Tiresias lhe tinha vaticinado'. ${ }^{93}$

Book XXIX contains a discourse pronounced by Minerva, now directly acting as a character of the novel, in which she dictates a blueprint for the constitution of Ithaca. Among her recommendations there is the promotion of agriculture based on local competitive advantages ${ }^{94}$ and of manufactures 'pelas multiplicadas utilidades que resultaõ aos povos de similhantes establecimentos, assim pela indipendencia em que se constituem de outros povos, como pelo emprego dos homens, e maior augmento do Commercio geral do Estado'. ${ }^{95}$ But the core of the chapter is represented by the description of the reforms introduced by Ulysses, now systematically accompanied by Telemachus, and, more interestingly, 'ajudado dos prudentes conselhos do grande Eurybato, (hum dos companheiros de Ulysses, que os Deoses tinhaõ preservado de todos os perigos, e que depois de ter corrido differentes climas, tinha ido parar a Creta, onde achando um navio dos Pheacios, se embarcou nelle para Ithaca, para ter o gosto de tornar a ver seu amo, e ajuda-lo á

Episódios, 2003, http://cvc.instituto-camoes.pt/ciencia/e31.html [accessed on 15th March 2014].

90 Aventuras de Telemaco, Filho de Ulysses, 2a ed. corecta e adicionada pelo mesmo tradutor da primeira versão das ditas aventuras, t. I (Lisboa, 1785); t. II (Lisboa, 1784); t. III, Aventuras Finaes de Telemaco, Filho de Ulysses, novamente compostas pelo bacharel Joseph Manoel Ribeiro Pereira, Secretario da Junta da Administraçaõ da Companhia Geral di Graõ Pará, e Maranhaõ, para serverem de continuaçaõ, e supplemento ás que em França compoz o sabio, e illustre Fenelon, e que já se achaõ traduzidas em Portuguez pelo mesmo Author desta nova composiçaõ (Lisboa, 1785). Silva, Diccionario, V, 9, mentions a second edition in two volumes of Pereira's translation dated from 1780. There is no reason to doubt that this edition existed, although we did not find it in Portuguese libraries. However the front page of the 1784-1785 edition declares this to be the second (amended) edition of the translation. Probably the version of 1780 was just a reprint of the first edition. Also Rodrigues, $A$ Tradução, 169, mentions the 1780 edition only basing himself on Silva's authority.

91 Silva, Diccionario, V, 9.

92 Also the numeration of books starts from the point at which Fénelon had arrived.

93 '...to spend the rest [of his life] more peacefully, in the company of his beloved Penelope, to see if in this way he could overcome his fate, and avoid being killed by his own son, as foretold by Tiresias's prophecy'; see Pereira, Aventuras Finaes, 213.

94 Pereira, Aventuras Finaes, 142.

95 '...for the further utility of nations that results from similar establishments, and also for the independence they assure from other nations, and for the employment of men, and the highest increase of the general Trade of the State'; see Pereira, Aventuras Finaes, 142-43. 
reforma de que necessitava o Reino)',.$^{96}$

No contemporary reader could miss that Telemachus appeared in this chapter as a personification of the Prince of Brazil, while Eurybatus was an avatar of the Marquis of Pombal (including his diplomatic experience abroad before becoming Secretary of State). But this occurred eight years after Pombal's fall and arrest, and seven years after the extinction of the Companhia do Grão Pará $e$ Maranhaõ. The conclusion is that Pereira was intentionally publishing a defence of the Marquis and his policies at a moment in which they had become anàtema. But if it is an objective truth that the Aventuras Finaes were published in 1785, it is far from being clear when they were actually written, and if there was a missing first edition published before 1777. Let us start from the latter question. As a matter of fact, the front page of 'volume three' 1785 edition describes it as a 'second edition'. There are two possible explanations for this annotation: either there actually was a first edition of Aventuras Finaes which has disappeared, or the phrase 'second edition' refers to the three volumes of the 1784-1785 edition as a whole (the same phrase does appear in the front pages of vol. 1 and vol. 2). But if there was a first edition of vol. 3, this was almost certainly later than 1780 , as Inocêncio da Silva describes the version published in that year as an edition in two volumes. He also considers the 1785 edition of Aventuras Finaes as the first edition of this work. This means that in any case Pereira's eulogy of Pombal was courageously published after the latter's fall.

But was Pereira's 'novel' written before or after 1777? There are various footnotes in chapter XXXII that refer to Pombal and José I respectively as current minister and the current king of Portugal. ${ }^{97}$ This seems to suggest that this text was written before 1777 , and incautiously left unchanged when the book was published in 1785. Was it incautiousness or an intentional strategy aiming at preserving the eulogy of Pombal with the excuse that it had been formulated earlier? An argument in favour of incautiousness is the poor editing of the book. There are a lot of misprints and inconsistencies, as if the author had taken no care of revising proofreads. It is possible that he forgot to update those footnotes that referred to past events, and he did not notice them when revising the text for print, or that he simply did not care about modifying them. But the secretary of the managing board of the Companhia could not be naïve in considering the political consequences of such an omission. And even the alternative hypothesis that the book had been printed before 1777, and published only later, does not allow us to exclude that there was a part of purposeful tacticism in leaving the eulogies of Pombal and his policies unchanged. ${ }^{98}$

Following the advice of Eurybatus, Ulysses creates a strong navy to defend Ithaca and the islands that were under its rule (i.e. its colonies!). ${ }^{99}$ Then he animates trade 'com regalias, e privilegios' [with patents and privileges], increasing the respect 'naõ só dos seus naturaes, mas

96 '...supported by the prudent advice of the great Eurybatus (one of Ulysses' companions, whom the Gods had preserved from all perils, and who after traversing different climates, had been to Crete, where he found a Pheacian boat and embarked on it towards Ithaca, for the sole desire to see his lord again, and to help him in the reforms needed by the Kingdom)', Aventuras Finaes, 156-57.

97 Note $(t)$ on p. 285 refers to a passage recommending the encouragement of exportation, and reads as follows: 'Systema este onde tendem todas as vistas politicas, e economicas do nunca assaz louvado Ministerio de Portugal'. Note $(u)$ on p. 287, commenting the suggestion to reduce or eliminate duties on internal trade, declares: 'Maxima esta que constitue o espirito de muitas, e repetidas Leis promulgadas no actual, e felicissimo Reinado do Senhor Rei D. Joseph o I'. Note $(y)$ on p. 288, referring to Ulysses' recommendation to honour Commerce, states: 'Doutrina assaz authorizada nos publicos testimunhos de honra, com que o nosso amabilissimo Monarca tem ondecorado esta Profissaõ'. Note $(z)$, p. 289 , commenting the view that in protecting trade the King should be supported by the advice of the 'Negociantes mais habeis', refers to the Junta de Comercio created by Pombal in the following terms: 'Maxima neste Reino praticada pelo establecimento da Junta de Commercio, Tribunal de quem emanaõ todas as decisões mercantis'. Finally, note $(a)$, p. 290 refers to Pombal's import substitution policy through national manufactures established by the government, and comments that the neglect of such an issue has been 'providamente acautelada pelas innumeraveis Fabricas estabecidas neste Reino para consumo dos generos do mesmo payz'.

98 There is a further and even more imaginative hypothesis: Pereira may have pretended he had written the book when Pombal was in power, to justify his eulogy as an apparent thoughtlessness. But such Machiavellian intentionality is in opposition with the quite anti-Machiavellian spirit of the book, which stresses the necessity for a king to be honest and to love truth in every circumstance. See e.g. Aventuras Finaes, 232-37.

99 Aventuras Finaes, 159. 
ainda dos outros povos de Argos, com os quaes começeraõ huma nova correspondencia, bem differente nos interesses á que antes com elles conservavaõ' ${ }^{100}$ It was easy for contemporary readers to recognise behind Argos the simulacrum of Great Britain, the ultimate target of Pombal's efforts to protect Portuguese trade. Immediately after, Eurybatus advices Ulysses to protect manufactures, ${ }^{101}$ and to expel from Ithaca those corrupted and unfaithful 'Sacrificadores' (clearly the Jesuits) who had tried to create an independent power at home and in the colonies, threatening the supreme power of the Prince and combating his attempted reforms. As a consequence, Ulysses had reformed education, formerly a monopoly of the 'Sacrificadores', and put it under the protection of the State. ${ }^{102}$

Assim se conservavaõ todas as differentes classes, concorrendo de maõ commum á utilidade publica. Banida a inveja dos corações, tanto se estimava a commodidade alheia, como a propria. Temeroso o engano do rigor das Leis naõ ousava a formar suas ordinarias caballas contra a boa fé do Commercio. As riquezas vendo o bom uso que dellas se fazia em Ithaca, corriaõ como de tropel a entrarem pelo porto, com tanta abundancia, que em pouco tempo pela sua opulencia começou a excitar o ciume das nações mais poderosas de Grecia. ${ }^{103}$

There is an irony in this defence of Pombal's interventionist policies: it largely contradicts Fénelon's project to base economic prosperity on agriculture, frugality and free trade. However, Fénelon and Pereira share the basic argument that the opulence and power of the nation is the object of an absolute monarch who takes care of his subjects. Furthermore, 'volume three' of Telemaco reflected one of the main aims of Pombal's project to protect Portuguese trade and stimulate manufactures, which was to guarantee a market to national agricultural products and to make terms of trade more favourable. ${ }^{104}$

But there is a further puzzle in this story. Pereira chooses as Pombal's avatar Ulysses' companion Eurybatus. This choice runs against a tradition that goes from Homer's Iliad to Dante's Comedy, which associates Ulysses to Diomedes. In Canto 26 of Inferno, both are condemned to hell as 'counsellors of fraud' for the way in which they convinced the Greeks to take Troy by force. But Dante considers them magnanimous and loyal to their country. The case of Eurybatus is different: an Eurybates is actually mentioned in the Odyssey (19.241) as Odysseus' squire, 'and Odysseus honored him above his other comrades, because he was like-minded with himself'. However, there is a whole tradition in European culture that associates the name of Eurybatus with the prototype of the traitor and the swindler. For example Diodorus Siculus in his Library describes the case of an 'Eurybatus of Ephesus', who was dispatched by 'Croesus, king of the Lydians, [...] to the Peloponnesus, having given him money with which to recruit as many mercenaries as he could from among the Greeks. But this agent of Croesus went over to Cyrus the Persian and revealed everything to him. Consequently the wickedness of Eurybatus became a by-word among the Greeks, and to this day whenever a man wishes to cast another's knavery in his teeth he calls him a Eurybatus'. ${ }^{105}$ And Erasmus, in Adagia, refers to 'eurybatizare' as a proverbial way of indicating immoral and criminal deeds of various kinds, including betrayal and corruption. ${ }^{106}$ It is unlikely that

100 '...not only of their fellow countrymen, but also of the other nations of Argos, with which the started a new relationship, quite different in terms of interests from the one they used to have with them in the past'; see Pereira, Aventuras Finaes, 161.

101 Pereira, Aventuras Finaes, 161.

102 Idem, 161-65.

103 'Thus all classes were equally preserved, and joined efforts to cooperate with public utility. Once envy was banned from hearts, the comfort of others was considered as important as private interests. Fearful of infringing on the rigour of Laws, nobody dared to conceive the usual cabals against the good faith of Commerce. Wealth, seeing the good employment that was made of it in Ithaca, hurried as though in a rush to reach port, with so much abundance, that in a short time Ithaca began to excite the jealousy of the most powerful nations of Greece because of its opulence'; see Pereira, Aventuras Finaes, 166. On this topos see Istvan Hont, Jealousy of Trade. International Competition and the Nation-State in Historical Perspective (Cambridge, MA, 2010).

104 Costa et al., História Económica de Portugal, 272-73.

105 Diodorus Siculus, The Library of History (Cambridge, 2004), 9.32.

106 Desiderii Erasmi Roterodami opera omnia emendatiora et auctiora, 2 vols (Lugduni Batavorum, 1703), I, 186; II, 
Pereira ignored this tradition, given the deep knowledge of the classics that shines through every page of his novel. But can we go up to suppose that his apparently eulogistic presentation of Eurybatus was actually a parody, and that Pereira was in fact deriding Pombal's policies? Such a hypothesis seems quite hard to believe, considering that Pereira was still in the place to which the then Conde de Oeiras had appointed him. But it is possible that he was conscious that the political climate had changed under Dona Maria's rule, and, without necessarily sharing their ideas, he left the door open to those who believed that Pombal was corrupted and an enemy of traditional social order. The choice of Eurybatus as a nickname for Pombal could be a way of admitting that those wise policies could have been the work of someone who, in the eyes of many, had eventually turned into a traitor. In other words, choosing such an avatar may have been a tactic to praise freely without being accused of anti-governmental propaganda.

In any case a similar politico-economic approach to trade is presented in the 'sábias, e discretas instrucções para bem reinar, e para fazer feliz o seu Reino, e o seu povo' ${ }^{107}$ given by Ulysses to Telemachus in the last two books of Aventuras Finaes. The framework is this time much broader, as the analysis of the economic duties of a wise king is preceded in Book XXXI by a detailed theory of the origins of government as a remedy to the permanent state of war among men. ${ }^{108}$ In such a condition individuals would easily accept to subordinate themselves 'a huma autoridade que lhes tirasse huma parte da sua libertade, pare lhes conservar a outra parte'. ${ }^{109}$ This passage clearly echoes the political theories of Montesquieu and Rousseau, although Pereira immediately specifies that such an argument works as a justification of absolute monarchy, and of the right to govern that kings derive from God ('[o] Soberano dos Deoses', in Ulysses' lexicon) as his representatives on earth. ${ }^{110}$ But the end of a sovereign is the good of his subjects, 'pois quem nasce para mandar, nasce para os outros, e naõ para si'. ${ }^{111}$ In order to govern 'pela razaõ' [by reason], a king must know his subjects. In this way he will be able to employ the best stimuli to promote the common good. ${ }^{112}$ And these stimuli are based on the universal desire for happiness:

Verás por experiencia propria quanto todos desejaõ ser felices; que todos tem este desejo em tudo quanto fazem; que todos se unem para ver se assim conseguem melhor este fim pelo mutuo soccorro que se communicaõ; que só, pela esperança de serem mais tempo felices, e com mais segurança, he que se sujeitaõ a hum Rei que lhe procure os meios, e que lhe possa vencer todos os obstaculos que elles particularmente naõ poderiaõ surmontar. ${ }^{113}$

Another element that reveals Pereira's familiarity with the Enlightenment culture is the egalitarianism on which this perspective is grounded. No privilege can be admitted, and the king, the aristocracy and the poor are equal in every respect. ${ }^{114}$ Therefore, in order to know his subjects, the king must put himself in their shoes and endeavour to feel what they really feel. ${ }^{115}$ Recompenses must be awarded according to merit, not to birth and as a favour. ${ }^{116}$ Finally, Pereira's egalitarian

86.

107 'wise and reasonable instructions to rule well, and to make his Kingdom and his people happy'; See Pereira, Aventuras Finaes, 212.

108 Pereira, Aventuras Finaes, 214-15.

109 'to an authority that takes off a portion of their liberty, in order to preserve the remainder'; See Pereira, Aventuras Finaes, 214.

110 Pereira, Aventuras Finaes, 216.

111 '...because he who was born to command, was born for the others, and not for himself'; See Pereira, Aventuras Finaes, 217.

112 Pereira, Aventuras Finaes, 221.

113 'You will discover by direct experience how much everybody desires to be happy; that everybody has this desire in everything he does; that all people associate themselves to see whether in this way they can better achieve this goal through the mutual help they provide each other; that only for the hope of being happy for a longer time, and with more security, they subordinate themselves to a King who provides them with the means, and who can remove all the obstacles that they would not be able to overcome'; see Pereira, Aventuras Finaes, 225-26.

114 Pereira, Aventuras Finaes, 260.

115 Pereira, Aventuras Finaes, 227-28.

116 Pereira, Aventuras Finaes, 253-54. 
views bring him to reserve a typically Pombalite bitter comment to aristocratic sentiments of superiority:

Naõ desprezarás infinitas cousas que ordinariamente escapaõ á ponderaçaõ dos Grandes; porque elles naõ se põe [sic] nunca no lugar dos pequenos, e já mais se persuadem que os outros homens tem a mesma sensibilidade que elles. ${ }^{117}$

It comes as no surprise that after a detailed analysis of the qualities required by the counsellors of the King, Pereira concludes that the perfect minister is ... Pombal: 'em fim, que seja hum homem tal come Eurybato, digno de ser teu amigo, como elle o foi meu'. ${ }^{118}$

Book XXXII is reserved to Ulysses-Pereira's views on political economy. The analysis responds to the distinction between 'qual deves ser' [how you ought to be], which is what Ulysses has indicated in Book XXXI, and 'o que deves fazer para bem governares o teu povo' [what you ought to do to well govern your people]. ${ }^{119}$ Interestingly, the first item in list of agenda is an indication to follow in every circumstance the Golden Rule of Jesus Christ. ${ }^{120}$ The sovereign must visit his country and get a direct knowledge of the conditions of every class, also as a way to learn 'que a tua principal obrigaçaõ he o amor do teu povo', ${ }^{121}$, and to make a detailed statistical study of his dominions in order to know the genius and customs of the various provinces, which jointly form ' $\mathrm{o}$ que se chama caracter geral da Naçaõ', ${ }^{122}$ the rents paid in the country, in order to understand when they can be increased or must be diminished for the good of the nation, ${ }^{123}$ the state of internal commerce and how it can be facilitated by the government through the construction of roads, canals, and by promoting security and transparency, ${ }^{124}$ the productivity of different lands whether it results from nature or from 'omissaõ', the population of various areas in order to understand how to support those which are underpopulated by supplying livestock and seeds. ${ }^{125}$ The list of duties continues with the administration of justice to secure the rule of Law, ${ }^{126}$ and finally political economy, a branch of the art of government which is modelled on Aristotelian oikonomia:

...pois assim como hum pai de familias, attento ao seu bem, e ao dos seus filhos, he a imagem mais natural de hum Rei attento ao bem dos sues vassallos, e do seu Reino, assim a economia do primeiro em conservar, e augmentar o que recebeo de seus pais, o seu desvelo, e amor pela tua [sic] familia, saõ o modelo de tudo o que deve fazer o Pai do Povo. ${ }^{127}$

Agriculture should be promoted because it guarantees national independence. ${ }^{128}$ Ulysses-Pereira looks favourably to small property, which stimulates productivity and secures patriotism. ${ }^{129}$ Such a condition must be encouraged by keeping rent ${ }^{130}$ low, so that peasants can save money to invest in

117 'Never disregard the infinite number of things that ordinarily escape the consideration of the Aristocrats; since they never put themselves in the shoes of the poor, and never admit that the others have the same sensibility than themselves'; see Pereira, Aventuras Finaes, 227.

118 '...finally, he must be a man like Eurybatus, deserving of being your friend, as he was mine'; see Pereira, Aventuras Finaes, 242.

119 Pereira, Aventuras Finaes, 259.

120 'Primeiro que tudo deves tratar os teus vassallos como quizeras ser tratado se obedeceras', Aventuras Finaes, 260.

121 '...that your principal obligation is to love your people'; see Pereira, Aventuras Finaes, 261.

122 '....what is called the general character of the Nation'; see Pereira, Aventuras Finaes, 264-65.

123 Pereira, Aventuras Finaes, 265-66.

124 Pereira, Aventuras Finaes, 266.

125 Pereira, Aventuras Finaes, 266-67.

126 Pereira, Aventuras Finaes, 268-78.

127 '...because as a householder who takes care of his own welfare and that of his children is the most natural image of a king who takes care of the welfare of his subjects and of his kingdom, so the economy of the former in preserving and increasing what he received from his parents, his zeal and the love of his family, is the model for whatever the Father of the People ought to do'; see Pereira, Aventuras Finaes, 278-79.

128 Pereira, Aventuras Finaes, 279-80.

129 Pereira, Aventuras Finaes, 280-82.

130 Pereira employs the term 'pensões', i.e. the rents paid in contracts of emphyteusis, which were typical of Portuguese agriculture in the $18^{\text {th }}$ century, especially to the north of Tagus. See Costa et al., História Económica de Portugal, 
the purchase of a small estate, and by supplying livestock and seeds in case of dearth. ${ }^{131}$ Agriculture is also encouraged by persuading the Aristocracy to take personal care of their estates. ${ }^{132}$ Such an approach echoes Pombal's efforts to favour a larger mobility of land property. ${ }^{133}$

As far as commerce is concerned, the protection suggested by Ulysses-Pereira is a typically product of the 'mercantile system': reducing importations and increasing exportations, in order to keep money inside the country, selling the surplus of national production and promoting domestic production. ${ }^{134}$ The protection of manufactures is based on a strategy of import substitution, 'pois será cousa bem reprehensivel deixares passar a mãos estranhas o que podia ser manufacturado pelas dos teus vassallos'. ${ }^{135}$ Industrial policies are aimed at maximising employment and avoiding the outflow of money even at the expense of efficiency and low prices. Only the importation of raw materials is admitted. ${ }^{136}$ The king must even reduce internal competition by avoiding to found new manufactures in already established industries. ${ }^{137}$ Labour-saving innovations must be equally discouraged, as '[o] teu maior cuidado ha de ser que todos vivaõ occupados, e possaõ ganhar pelo seu trabalho com que se sustentem'. ${ }^{138}$ Ulysses-Pereira goes as far as arguing that awarding prizes to inventors does not involve licensing their inventions, when the latter are prejudicial to the poor and encourage idleness. The distance between this ideal of regulated industrialisation and classical laissez faire can be measured by the concluding mistrustful remarks of competition:

destes dois grandes males [unemployment and idleness] he mui tenue a compensaçaõ de ter as cousas por melhor preço, pois esta diminuiçaõ he mui pouco sencivel, ao mesmo tempo que he mui pezado o encarego a que fica sujeito o Estado com huma multidaõ inutil. ${ }^{139}$

Pereira's attitude to luxury is ambiguous and quite distant from Fénelon's ideas: excessive luxury should be in principle discouraged. ${ }^{140}$ However it can be tolerated 'pelo bem do Commercio' [for the good of commerce], although not 'alem dos limites, que a utilidade publica lhe prescrever' [beyond the limits prescribed by public utility]. Allowed luxury productions are those 'que servirem á navegaçaõ, ao fabrico das lãas, sedas e armas, e a todas, em fim, que sendo materia do Commercio, contribuem a occupar utilmente o povo, e a exercitar o seu trabalho, e industria, banindo do Reino a ociosidade, e a indigencia'. ${ }^{141}$

Finally, the king should promote the sciences more for the prestige they guarantee than for their practical consequences. ${ }^{142}$

The rest of the book is devoted to defence, the final duty of a sovereign. This subject allows Ulysses-Pereira to examine the topic of taxation. Taxes are an attribute of sovereignty and must be obeyed without exception. Nevertheless the king has duty to levy moderate taxes by maintaining

222-23.

131 Pereira,_Aventuras Finaes, 282.

132 Pereira,_Aventuras Finaes, 283.

133 Costa et al., História Económica de Portugal, 221-22.

134 Pereira, Aventuras Finaes, 285-89. 'He preciso para ser feliz hum Reino, que necessite pouco dos outros, e que os outros naõ possaõ deixar de commerciar com elle: de outra sorte se exahurirá o dinheiro, naõ tendo nada que vender, e virá a ficar pobre se tiver que comprar tudo o que necessitar aos mais' (285).

135 '... since it is a very reprehensible thing to leave to foreign hands what could be manufactured by those of your subjects'; see Pereira, Aventuras Finaes, 289-90.

136 Pereira, Aventuras Finaes, 290.

137 Ibidem.

138 'your main concern must be that all are employed, and that they are able to gain their subsistence thanks to their labour'; see Pereira, Aventuras Finaes, 290-91.

139 'it is quite a weak compensation for these two large evils to have things at a better price, as this reduction of little significance, whereas the burden to which the State is subjected by a useless multitude is very heavy'; see Pereira, Aventuras Finaes, 291. In order to discourage laziness, Pereira suggests to import efficient foreign manpower to stimulate emulation (291-92).

140 Pereira, Aventuras Finaes, 292-93.

141 '... which are useful to navigation, to the fabrication of wool, silk and arms, and finally to all those which, being the subject of commerce, contribute to usefully employ the people, and to excite their labour and industry, banishing from the kingdom laziness and indigence'; see Pereira, Aventuras Finaes, 295.

142 Pereira, Aventuras Finaes, 293-95. 
and exact proportion between taxes and expenditures. ${ }^{143}$

It is clear that the consistency between books I and II and book III was very weak especially on the issues of political economy, where Pereira sided with Pombal. As we shall see, the economics of Aventuras finaes was quite consistent with that of the Elementos do commercio. It goes without saying all these efforts did not win to Pereira an election to the Academy.

\section{Translation as paraphrasis}

The Elementos do commercio, like any other translation by Pereira, are a presented as a free translation, made in a 'paraphrastic style', a choice that was controversially received by his contemporaries. The most analytical discussion of this method is contained in the preface to the translation of Fléchier. Pereira maintains that the main goal of his work is 'a esperansa da utilitade publica' [the hope of public utility]. ${ }^{144}$ It can be demonstrated that this patriotic bent is a sign of the times, as it considers literary production, especially translation, as part and parcel of a political programme of reform.

But let us consider first Pereira's own explanation of the benefits of the paraphrastic style:

A vista de tantas maravilhas despertou em mim o dezeio de traduzilas, atendendo a que pouco importava aver no orbe Literario tam prosioza eloquensia àqueles, que ignorando o idioma Fransez se nam podiam utilizar de suas raridades. Perplexo no estilo, que seguiria, da traducsam, me rezolvi com Horacio a seguir a parafrastica, de que uzou Cicero nas duas orasoens que traduzio de Esquino, e Demostenes; desprezando a literal, a que tanto se inclina o vulgo mais escrupolozo que prudente. ${ }^{145}$

Pereira equals literal translation to pedantic and abstruse work. More interestingly, he bases his justification on two classical sources that were very often cited in Portuguese $18^{\text {th }}$-century debates on translation: a passage of Horace's Ars Poetica (133-34) containing a recommendation to translators: 'Nec verbum verbo curabis reddere fidus | intepres'; and Cicero's De Optimo Genere Oratorum $(5,14)$, where the author refers to his own translations of Aeschines and Demosthenes and argues that, in order to be perfect a translation must correspond on the one hand to the ideas rather than to the words of the original, and on the other hand to the aesthetic (elegance) of the translator's language. ${ }^{146}$ Pereira insists that an eloquent literary work must be translated in an equally eloquent style, and this implies that "variando de lingua, sem que variaze de frases, viria a ser fastidioza leitura o que era antes deleitavel instrucsam, e lucraria por fruto do trabalho o diminuir os creditos do autor, quando só o meu empenho é enobrecerlhe a memoria, e, dilatando-lhe a fama, aumentarlhe a gloria'. ${ }^{147}$

As a matter of fact, neither Horace nor Cicero define their preferred method of translation as paraphrastic. Pereira probably derived the term from the categorisation of types of translation proposed by the Portuguese clergyman and grammarian Amaro de Roboredo in the introduction to the Porta de Linguas, ${ }^{148}$ an adaptation of the Ianua Linguarum published by the Irish Jesuits of Salamanca twelve years before. Roboredo listed four types of translation: literal translation, which

143 Idem, 297-99.

144 Compendio, [1].

145 Compendio, [3-4]

146 'Converti enim ex Atticis duorum eloquentissimorum nobilissimas orationes inter seque contrarias, Aeschini et Demostheni; nec converti ut interpres, sed ut orator, sententiis isdem et earum formis tamquam figuris, verbis ad nostram consuetudinem aptis', M. Tullius Cicero, "De Optimo Genere Oratorum" in Rhetorica, A.S, Wilkins ed., 2 vols (Oxford, 1911), 5,14 See Compendio, [4].

147 'by changing the language without changing sentences, what before was pleasant instruction would become annoying reading, and the revenue of this work would be diminishing the credit of the author, when my only commitment was to ennoble his memory, and, by expanding his fame, to increase his glory', Compendio, [4-5].

148 Amaro de Roboredo, Porta de Linguas (Lisboa, 1623), 22-25. See Monica Lupetti, Dalla Ianua alla Porta. Il metodo di Amaro de Roboredo al crocevia della riflessione linguistica secentesca portoghese ed europea (Pisa, 2010), $85-88$. 
'faze-se de tal maneira ao pee da letra; que toda a frase da língua que traduzimos se observa'. ${ }^{149}$ The result is that '[a]s palavras são Portuguesas, a frase Latina, a tradução absurda' ${ }^{150}$ The second type of translation is still quite literal, although it takes into account the fact that sentences are not constructed in the same way in different languages. In order to formulate the same concept, different languages use a different number of words (for example articles, prepositions) and place them in a different order. By restructuring the sentence according to the rules of the language of destination, the reader can almost understand its literal meaning. The third type is the translation 'por cláusulas' [by clauses], in which every language is categorised according to its own idiomatic terms and sentences, and the goal is to find a concordance between them whenever possible. This kind of translation is the most elegant. But it requires a deep knowledge of both languages and can only be the result of a long process of education in which the teacher helps students to create clauses from memorised sentences and then reformulate them in the language of destination. Finally, there is the paraphrastic translation. Roboredo insists that it is the most difficult type of translation, requiring an already mature proficiency in the third type, "porque respeita sômente o conceito do periodo, quer uses da mesma frase, quer de diversa: hora exclua algüas palavras, hora ajuntes mais'. ${ }^{151}$ It is important to realise that, according to Roboredo, paraphrastic translation must be accurate and rigorous in its own way: it is aimed at clarifying the concepts expressed in the original sentences, not at modifying their meaning with arbitrary interpretations and digressions.

In the preface 'A Quem Ler' of Pereira's translation of Télémaque, the translator, in line with Cicero's recommendations, presents his translation as faithful to content and eloquence rather than to the letter.

The validity of his method of translation was openly challenged by Manuel de Sousa in the preface to his 'counter-translation' of Télémaque (1770). Most of the preface was devoted to a discussion of the methods of translation. Sousa diplomatically argued that Pereira's genius was more apt to original production than to translation, and this genius did not allow him to 'ligarse ás prizoens de huma rigoroza traducçaõ'. ${ }^{152}$ Therefore Pereira

... despedaçou os grilhoens, e fez em partes mais huma nova composiçaõ, do que huma versaõ fiel, deixando o que the pareceo afectado, e accrescentando o que entendeo que a affermoseava, e servia para melhor se entender; a isto chamaraõ os maledicos desfigurar a obra, argumentando da fecundidade do engenho do Traductor pobreza, e falta de propriedade na lingoagem, e que se omittira algumas bellezas, eraõ por serem de tal formosura, e energia que só na lingoa Franceza se mostravaõ com magestade, e até nos lugares que ampliou davaõ por culpada a lingoa de defeituosa, inculta, e sem concisaõ. ${ }^{153}$

Manuel de Sousa rhetorically attributes to some 'evil tongues' a critique he actually shares: the way in which Pereira applied the paraphrastic method disfigured the work by removing its stylistic beauties and replacing them with prolixity and uncultivated language.

Sousa opposed to Pereira's paraphrastic translation a more literal one. But he shifted the ground of emulation as it were from rephrasing to restyling. The new translation he offered was allegedly more faithful to the original narration and aimed to equal 'pela propriedade e elegancia os lugares mais bellos', ${ }^{154}$ although it improved most passages 'pela energia, concisaõ, abundancia e nobreza

\footnotetext{
149 '... [it] is done so literally, that all the sentence of the language we translate can be recognised' (Roboredo, Porta de Linguas, 23).

150 'Words are Portuguese, the sentence is Latin, the translation is absurd' (Roboredo, Porta de Linguas, 23).

151 '...as it only respects the meaning of the period, either using the same sentence, or a different one, sometimes excluding some words, and sometimes adding some more'.

152 '...to tie himself to the chains of a rigorous translation', O Telémaco, [not numbered].

153 '.... [he] shattered fetters, and in some places he made more a new composition, than a faithful version, leaving aside what appeared to him pompous, and adding what he believed to embellish it, and what was instrumental to its understanding; this was what evil tongues called a way of disfiguring the work, drawing from the fecundity of the translator's ingenuity an impression of poorness and lack of propriety in language, and that if he omitted some beautiful passages, it was because they were of so great a beauty and energy, that they could appear majestic only in French, and even in the passages he amplified they charged the language to be defective, uncultured, and lacking concision', O Telémaco, [not numbered].

154 '...in propriety and elegance the most beautiful passages', O Telémaco, [not numbered].
} 
de termos, e frases'. ${ }^{155}$ This approach reminds us of Roboredo's translation 'por cláusulas', also because he declared that the condition of possibility for improvement was less the subjective quality of the translator than the large stock of 'termos, e frases que encontravamos nos Authores que escreveraõ polidamente em Portuguez' ${ }^{156}$ By this appeal to the glories of Portuguese literature, Sousa, who as we know was a connoisseur, introduced here another topos that had been canonised since the $16^{\text {th }}$ century, in the cultural climate of Renaissance ${ }^{157}$ and as a consequence of the imperial expansion of Portugal, which established a strong connection between conquest and affirmation of Portuguese as an institutional language for communication. ${ }^{158}$ Both the Dialogo em Louvor da Nossa Linguagem, by João de Barros (1540), ${ }^{159}$ and the Dialogo em Defensaõ da Lingua Portuguesa, by Pêro de Magalhães de Gândavo (1574) ${ }^{160}$ argued that the superiority of Portuguese over French should be attributed to the fact that the latter, 'bem que seja muito abundante de termos abstractos, naõ o he nem ainda medianamente provido de palavras energicas, que naõ provém das faculdades'. ${ }^{161}$ The proof of such a superiority of Portuguese was offered by Sousa's translation, since 'a cada passo nos termos, e frases que parecem mais escabrosas de passar a nossa lingoa, se nos offereciaõ algumas vezes em tanta abundancia frases iguaes, e talvez melhores, que pendiamos indecisos na escolha'. ${ }^{162}$ Sousa went on along this patriotic register by condemning the increasingly fashionable employment of 'Gallicismos' in translations and in technical texts. Not only did writers very often ignore the correct meaning of the loans they adopted. They also committed a political crime against national identity, national history and the legal and political constitution Portugal:

... todas as palavras, de que desdenhaõ, saõ aquellas com que se explicaõ os Escriptores que fazem o fundamento da nossa lingoa, as Leis, Ordenaçoens, e Constituçoens, com que nos regemos, e os Alvarás, e Patentes com que o Monarca nos honra, e muitas saõ usadas nas Leis modernas do nosso Soberano, o que faz com que as hajamos de respeitar, e em certo modo nos authoriza para podermos usar das outras, pois nos dá a entender, que tanto as naõ regeita que no mesmo usar d'humas nos dá abono para as outras. ${ }^{163}$

Also in the case of neologisms necessarily created to reconstruct 'o estillo heroico desta casta de composiçaõ', ${ }^{164}$ Sousa took care 'sempre en que tirassem da boa fonte a sua origem, e da mesma d'onde emana a nossa lingoa, imitando nisto a todos os bons Escriptores, que por este modo locupletaraõ a sua lingoa, adoptando termos energicos, e significativos que tirassem a sua origem ou de outros termos da mesma lingoa, ou de outra d'onde a sua emanara...'. ${ }^{65}$. Based on the topos of

155 '...for the energy, conciseness, abundance and nobleness of terms and sentences', $O$ Telémaco, [not numbered].

156 '.... terms and sentences we found in the Authors who delicately wrote in Portuguese', $O$ Telémaco, [not numbered].

157 See María Manuela Fernández Sánchez and José Antonio Sabio Pinilla, 'El Humanismo renacentista y la traducción en Portugal en los siglos XVI y XVII', in Seis estudios sobre la traducción en los siglos XVI y XVII, edited by José Antonio Sabio Pinilla and Maria Dolores Valencia (Granada, 2003), 205-42.

158 See Monica Lupetti, 'Forme testuali e strategie retoriche di elogio della lingua portoghese nei secoli XV e XVI', in Forme e occasioni dell'encomio tra Cinquecento e Seicento, edited by Danielle Boillet and Liliana Grassi (Lucca, 2011), 297-312.

159 João de Barros, Dialogo em Louvor da Nossa Linguagem (Modena, 1959).

160 Pêro de Magalhães de Gândavo, Regras que Ensinam a Maneira de Escrever e a Ortografia da Língua Portuguesa, com o diálogo que adiante se segue em defensão da mesma língua (Lisboa, 1982).

161 '...despite its richness of abstract terms, it is below average in the stock of energetic words, which do not derive from faculties', $O$ Telémaco, [not numbered].

162 ....at each step on the terms and sentences that appeared most difficult to render in our language, sometimes so many equivalent sentences presented themselves to us, and sometimes some better ones, that we remained uncertain in the choice', $O$ Telémaco, [not numbered].

163 '.... all the words they disregard are those employed by the Writers who laid the foundations of our language, as well as by the Laws, Regulations, Constitutions by which we govern ourselves, and by the Appointments and Patents with which the King honours us. And many of them are employed in the modern Laws of our Sovereign. This is the reason why we must pay respect to these words, and in a certain way this allows us to use the other ones [i.e. those of French origin], as it lets us understand that the latter must not be rejected to such an extent, that using the former forbids us to use the latter', $O$ Telémaco, [not numbered].

164 'the heroic style of this kind of composition', O Telémaco, [not numbered].

165 '[Sousa] always [took care] to derive them from the right source, the same from which our language emanates, so 
Portuguese as the most ancient language because of its proximity to Latin, this passage implies that Latin was a legitimate source for neologisms in a strategy aiming at nationalising foreign literature through translation. ${ }^{166}$ Significantly, Sousa concludes this strategic declaration with an economic metaphor:

Porque, qual he o homem que se agaste se aos seus muitos cabedaes lhe juntar hum amigo boa soma de moeda de Lei? Engeita-la ha ao portador, ou elle hido, arroja-la ha pela janella? Pois nada menos obraõ os que se enjoaõ de ver huma palavra ou antiga, e bem soante, e energica, ou nova vinda da Latina com bom cunho, que nos poupe huma circumlocuçaõ; e o mais he que agasalhaõ com boa sombra huma Franceza, ou Italiana. ${ }^{167}$

Manuel de Sousa's critique reflected the most widespread attitudes of the age vis-à-vis translation. Paraphrastic rendering was far from being popular, and Pereira was quite isolated at least in openly defending it. For example, Inocêncio da Silva writes about Luís do Couto Félix's translation of Tacitus' Annals (1715), that '[a] obra, como tradução, vale pouco ou nada. É antes uma estiradíssima paráfrase, em que os períodos curtos e concisos do texto aparecem como que afogados no mar de reflexões e comentários do tradutor'. ${ }^{168}$ However, in the 'Prólogo a quem quiser ler', Félix more prudently presents his translation as 'política e não é rigorosa, ou mais filosófica que gramática, em que sempre a razão tinha melhor lugar que a língua'. ${ }^{169}$

But Félix is probably one of the last who so directly rejects 'fiel' [faithful], 'palavra por palavra' [word by word] translation as a source of 'molestia' [molestation] and 'infelicidade' [infelicity], 'porque a prisão, ou o medo de sair fora das linhas do original, não the deixa liberdade para um rasgo'. ${ }^{170}$ In the Pombaline era the creation of academies, the reform of education and a more philological attitude stimulated translators to adopt a more rigorous approach to their activity. ${ }^{171}$ In the 'Discurso preliminar do tradutor' to the first out of seven translations of Horace's Ars Poetica that appeared in Portugal in the $18^{\text {th }}$ century, ${ }^{172}$ the Oratorian Father Francisco José Freire, a member of Arcádia Lusitana under the name of Cândido Lusitano, dictated the 'Condições precisas para a boa Tradução [exact conditions for a good translation]'. Like Pereira, he quoted Horace and Cicero, although he reached an opposite conclusion:

Desta autoridade claramente se colhe que a Tradução, para ser boa, é preciso que conserve com a fidelidade possível todo o carácter e índole do texto, sem que seja necessário mostrar-se de um certo modo supersticioso em copiar o seu painel toque por toque. ${ }^{173}$

imitating the good Writers, who in this way enriched their language, adopting energetic terms, and meaningful ones, which derived from other terms of the same language, or from another from which their own language emanated', $O$ Telémaco, [not numbered].

166 '...sempre as derivo d'outras Portuguezas, ou do Latim d'onde emana a nossa lingoa', O Telémaco, [not numbered].

167 'For, who is the man who is annoyed if a friend adds to his many capitals a nice sum of good legal money? Shall he give it back to the bearer, or, once he is gone, throw it out of the window? Because no different is the behaviour of those who rejoice at seeing either an old and well sounding and energetic word, or a new one coming from Latin with a good imprint, which spares us a cicumlocution; and, what is more, they wrap with a good shade a French or Italian word', O Telémaco, [not numbered].

168 'The work, as a translation, has little or no value. It is above all a thorough paraphrasis, in which the short and concise periods of the text appear as it were drowned in the sea of the translator's reflections and comments', Silva, Diccionario, V, 281.

169 '...polítical rather than rigorous, or philosophical rather than grammatical, in which reason occupies a better place than language', Luís do Couto Félix, 'Prólogo a Quem Ler', in Tacito Portuguez, ou Traducçam Politica dos tres Primeyros Livros dos Annaes de Cornelio Tacito (Lisboa, 1715); reprinted in Sabio and Fernández, O Discurso, 82$84(82)$.

170 '....as the prison, or the fear to get out of the lines of the original, do not leave to it the liberty for a scratch', Félix, 'Prólogo', 82-83.

171 Sabio and Fernández, O Discurso, 36-40.

172 Idem, 38.

173 'From this authority we clearly hold that a Translation, in order to be good, must keep both the most possible fidelity to, and the character and genius of, the text, without necessarily showing oneself in a way superstitious in copying one's frame bit by bit', Francisco José Freire (Cándido Lusitano), 'Discurso preliminar do tradutor', in Arte Poetica 
Freire's keywords in this interpretation were 'Fidelidade' and 'Carácter'.

Nós por fidelidade não entendemos o traduzir literalmente; mas sim o exprimir (quanto for possível) sentença por sentença, e figura por figura, não acrescentando cousa que não se leia no original, e não menos tirando ou mutando cousas que nele estejem. ${ }^{174}$

It is easy to recognise in this passage an implicit reference to Roboredo's translation 'by clauses', as well as the influence of the Italian humanists. As to the character of a translation:

O carácter, ou índole, consiste em saber conservar na Tradução a mesma gala, o mesmo ar, nobreza e afectos com que se exprime o texto, a cuja circumstância propriamente chamavam os antigos Cores. De sorte que, para haver fidelidade, é preciso ciência, e para haver esta índole, é necessário eloquência. ${ }^{175}$

The new ideal was therefore one of fidelity as opposed to paraphrasis, ${ }^{176}$ and of aesthetic imitation. Fidelity did not mean pedantic word-by-word rendition, but a philological approach deeply based on erudition and on translation 'by clauses'. As argued by António Lourenço Caminha in the preface to his translation of Cicero's Laelius de Amicitia, '[s]er Tradutor não é ser Compositor. A versão há-de ser como uma fiel embaixada, aonde o Legado não deve alterar mais do que lhe ordenou o seu Soberano. É um fiel expelho que só copia o objecto tal que ele é em si próprio; ou como, finalmente, uma pintura que se copia de outro quadro'. ${ }^{177}$

Other interpreters, however, though sharing Cândido Lusitano's ideal of substantive fidelity, were not convinced that preserving the 'colours' of the original was the final end of a translation. A text translated into Portuguese did more than imitating the original style: it positively emulated it, thanks to the superior variety and elegance of Portuguese over other languages. It is in this way, as Manuel de Sousa, and more implicitly José Manuel Pereira had argued, that a translation becomes a political act of national emulation. ${ }^{178}$ In the case of Portugal, it seems however more exact to speak of a 'nationalisation' of useful alien contents through their reformulation in a domestic style that produces a new, superior result of aesthetic beauty and linguistic plentifulness. This is for example what Custódio José de Oliveira prudently argued in his 'Prefação' to the Portuguese translation of the Treatise on Sublime. His text opposed the 'beleza do original' [beauty of the original] and the 'força dos pensamentos' [power of thoughts] of the source text to the research that the exercise of translation obliges us to do 'para achar frases próprias com que expressemos quanto pensa o mesmo original'. ${ }^{179}$ By translating we discover 'a variedade e abundância' [the variety and abundance] of

de Q. Horácio Flacco (Lisboa, 1758); reprinted in Sabio and Fernández, O Discurso, 91-99 (92).

174 'By fidelity we do not mean translating literally; we mean phrasing (as much as possible) sentence by sentence, and figure by figure, not adding things that cannot be read in the original, and neither suppressing nor changing what is inside it', Freire 'Discurso preliminar', 92.

175 'The character, or genius, consists of being able to preserve in a Translation the same solemnity, the same air, nobleness and affections that are expressed in the text, which circumstance was precisely called by the ancients Colours. It follows that, in order to have fidelity, we need science, and in order to have such a genius, we need eloquence', Freire 'Discurso preliminar', 92.

176 See for example João Rosado de Vilalobos e Vasconcelos, 'Prefação', in Os Tres Livros das Instituçoens Rhetoricas de M. Fab. Quintiliano (Coimbra, 1782); reprinted in Sabio and Fernández, O Discurso, 128-31 (130), who opposes 'thought by thought' translation to paraphrasis; and José António da Mata, 'Prólogo', in Odes do Poeta Q. Horacio Flacco (Lisboa, 1783); reprinted in Sabio and Fernández, O Discurso, 132-34 (133), who curiously interprets Horace's phrase in Ars Poetica (1-5) as an argument against paraphrasis and mere imitation!

177 'To be a Translator is not the same thing as being an Author. A version ought to be like a faithful message, where an Ambassador must not change more than what his Sovereign ordered him. It is a faithful mirror that copies the object as it is in itself; or lastly it is like a painting copied from another picture', António Lourenço Caminha, 'Prólogo', in Lelio, ou Dialogo sobre a Amizade Dedicado a Tito Pomponio Attico (Lisboa, 1785); reprinted in Sabio and Fernández, O Discurso, 134-37 (137).

178 See Sophus Reinert, Translating Empire. Emulation and the Origins of Political Economy (Cambridge, MA, 2011).

179 '... to make appropriate sentences by which we express what the original argues', Custódio José de Oliveira, 'Prefação', in Dionysio Longino, Tratado do Sublime (Lisboa, 1771); reprinted in Sabio and Fernández, O Discurso, $100-104(100)$. 
the language of Camões.

Que melhor educação e cultura do que o trabalho de traduzir e imitar aqueles Escritores que nos podem servir de seguros Mestres, em cujas obras um sólido engenho pode encher a sua alma das virtudes que quer imitar, transportando-se a fazer própria na sua língua a produção dos pensamentos, expressões, frases e teor da obra estranha, com todas as cores, figuras, naturalidade, força, viveza, graça, majestade, que se encontra na língua que traduz, buscando conservar e suster o carácter, harmonia e estilo do seu Autor, sem se encostar a cada uma das palavras para as seguir conforme a sua ordem, o que todavia mostra servidão e esterilidade de génio. Deste modo fica a tradução parecendo não só uma verdadeira cópia do original, mas outro segundo original... ${ }^{180}$

In the same vein, Miguel do Couto Guerreiro, offering a new translation of Horace's Ars Poetica, warned his readers that he attempted to 'mudar e traduzir Horácio em Português, de modo que pareça nativo e não transplantado', ${ }^{181}$ thus producing a 'Horácio Português'. A similar national pride emerged from the preface to the translation of Quintilianus' Institutio Oratoria, another key text for the Portuguese culture of the $18^{\text {th }}$ century. The Oratorian Father Vicente Amado (Vicente Lisbonense), the author of this translation, rhetorically formulated the wish that there may be a time when a better translation may appear, and 'que nos poderíamos ter uma tradução de Quintiliano, que fosse digna dele, digna dos Portugueses, e digna do século em que estes florescem tanto nas Ciências e Artes'. ${ }^{182}$

Another Oratorian Father, António Joaquim, who shared Cândido Lusitano's ideal of fidelity, introduced a further argument in this discussion: a rich language like Portuguese is ideal for translation, because it requires less neologisms than any other. And those who employ many neologisms simply do it because they are ignorant! 'Semelhante género de argumento e prova seria muito material, mas se o nâo fosse, diria eu que a língua Portuguesa era a mais vasta e abundante de todas as de Europa, porque nenhuma tem mais voluminoso Dicionário'. ${ }^{183}$

Not surprisingly in some cases the discourse on translation of the Pombaline era and of the early years of Queen Maria's reign shifted from imperial patriotism to politico-economic rivalry. The Anonymous translator of Nicolas de la Clède's Histoire générale de Portugal (Paris, 1735) justified the Portuguese translation of this work by two connected reasons. Firstly, the original had become rare on the Portuguese market and was very expensive. It would be a paradox for ' $[\mathrm{t}]$ odo aquele Homem, que por capricho não quiser ostentar desdenhoso desprezo das cousas do seu País' ${ }^{184}$ to be obliged either to buy such expensive copies or to 'revolverem grossos e pesados Volumes, que já

180 'What better education and culture than the work of translating and imitating those Writers who can be considered as sure Masters, in whose works a strong understanding can fill his spirit with the virtues he aims to imitate, applying himself to appropriate in his own language the production of thoughts, phrases, sentences and wording of the foreign work, with all the colours, figures, simplicity, force, vividness, grace, majesty that can be found in the translating language, trying to preserve and sustain the character, harmony and style of its Author, without leaning back to every single word to follow them according to their order, which however shows serfdom and sterility of genius. In this way the translation comes to appear not only as a true copy of the original, but a second original', Oliveira, 'Prefação' 102-103.

181 '... modify and translate Horace in Portuguese, in such a way that he may appear native instead of transplanted', Miguel do Couto Guerreiro, 'Ao Leitor', in Arte Poetica de Horacio Traduzida em Rima (Lisboa, 1772), v-xvi; reprinted in Sabio and Fernández, O Discurso, 105-107 (106).

182 '... that we may be able to have a translation of Quintilianus that may be worth him, worth the Portuguese, and worth a century in which the latter flourish so much in Sciences and Arts', Vicente Amado (Vicente Lisbonense) 'Prefação do tradutor', in Quintiliano, Da Instituição do Orador, I (Lisboa, 1777); reprinted in Sabio and Fernández, O Discurso, 107-10 (110).

183 'A similar kind of argument and proof would be very material. But if it were not, I would say that Portuguese is the broadest and abundant among the European languages, because no one has such a voluminous Dictionary', António Joaquim, 'Prólogo', in Orações Principaes de M.T. Cicero, Vol. I (Lisboa, 1779); reprinted in Sabio and Fernández, O Discurso, 111-13 (112).

184 'All those Men, who by chance do not wish to display a disdainful contempt for the affairs of their country', 'Prólogo do tradutor' in Historia Geral de Portugal por Mr. de la Clede, 16 vols, I (Lisboa, 1781); reprinted in Sabio and Fernández, O Discurso, 114-16 (114). 
custam achar a quem tem a mesma História, que lá escreveu o Autor Francês' ${ }^{185}$ This translation, supplied for 'muito mais de metade do preço, por que a pagam em Francês', ${ }^{186}$ was therefore a firstbest alternative to the original. Like the goods produced by Portuguese national fábricas this book substituted the importation of its original. But unlike most of them, it was cheaper than imported manufactured goods and also cheaper than existing domestic alternatives! That is probably the reason why the Anonymous translator defined his work as a 'presente' [gift] made to the Portuguese nation. $^{187}$

The second reason that justified this translation was a concern for the negative effects on national pride of a foreign book that displayed in some cases an open hostility towards Portuguese history. The response to this problem was very much in line with Pereira's attitude: the translation of M. de la Clède's history had been made by consulting national historiography, "não somente para verificar os factos que escrivia e restituir fielmente os nomes proprios, que sem esta diligência não tornariam facilmente ao seu proprio estado depois de passarem a Francês'. ${ }^{188}$ This however was not paraphrasis: it was revision and adaptation. And the end in view was the nationalisation of the original French contents. In this way the translation of La Clède was a substitute for importation not only in material and economic terms, but also in cultural terms.

Pereira's defence of the paraphrastic approach was maintained in his last translation, that of Young's Nights. An implicit response to his critics is contained in the 'Discurso preliminar, Que contêm hum breve extracto da Vida de Young, com algumas reflexões do seu genio, e das suas Noites, e sobre esta Traducçaõ', which is actually an adaptation of Le Tourneur's 'Discours préliminaire', prefaced to the French edition of 1769. Towards the end of this text, however, Pereira interpolates some original paragraphs in which he discusses his own criteria. His interventions are motivated by two reasons: avoiding 'repetiçaõ de idéas', and omitting those passages 'que julguei naõ seriaõ bem acceitas pelos seus assumptos'. ${ }^{189}$ The result he has obtained in this way is

...mais huma paraphrasi, que huma traducçaõ, procurando tirar do Young Inglez, e Young Francez, hum Young Portuguez, que podesse agradar á minha Naçaõ, cujo methodo, que sigo nesta versaõ, e nas mais que tenho feito, he nascido da persuasaõ, em que estou, de que assim se deve traduzer Authores de linguas estrangeiras, e muito proncipalmente aquelles, que sendo de superior merecimento pela materia que trataõ, naõ o lograõ igual pelo gosto, e digestaõ com que escrevem. Desta sorte cuido eu que facilmente nos póde ser proprio o bom dos visinhos, deixando-lhe o máo que naõ necessitamos ler, nem conhecer. ${ }^{190}$

Paraphrasis is therefore the way in which, according to Pereira, a translator can render the superior contents of an original written in a foreign language into a Portuguese language and a Portuguese style, which positively improve the original. Rephrasing is the true way to nationalising foreign literature. Pereira never employs politico-economic metaphors, but his way of describing his method of translation is clearly isomorphic to the discourse on Pombaline commercial and industrial policies: useful literature has to be imported as a raw material, but its manufacture has to

185 '...consume themselves on big and heavy Volumes, which are already hard to find for those who have the same History, about which the French Author wrote there', 'Prólogo do tradutor', 114.

186 '...much less than half the price they pay for the French version', 'Prólogo do tradutor', 114.

187 The activity of translating is compared to trade also by Jerónimo Soares Barbosa, 'Prefação', in Marcus Fabius Quintilianus, Instituçoens Oratorias (Coimbra, 1788); reprinted in Sabio and Fernández, O Discurso, 138-42 (138), who argues that 'se o comércio das fazendas é tão vantajoso, e ainda necessário às indigências da vida, o dos conhecimentos não o deve ser menos aos espíritos que sentem a necessidade de instruir-se, e não têm o meio de o fazer, que são as línguas'.

188 'not only to verify the facts the author wrote and to restate the exact proper names, which without this diligence would not revert to their own state after being transposed into French', 'Prólogo do tradutor', 115.

189 Noites Selectas de Young, xiv.

190 '...more a paraphrasis, than a translation, aiming at deriving from the English Young and the French Young a Portuguese Young, who might please my Nation; whose method, which I follow both in this version and in the others I did, originated from the persuasion that Authors writing in a foreign language must be translated in this way, and mainly those who, being of superior merit for the subject they approach, do not reach the same merit for the taste and meditation by which they write. In this way I believe that the good of our neighbours can be our own, leaving to them the bad we neither need to read nor to know', Noites Selectas de Young, xiv. 
be entirely processed through Portuguese language and Portuguese style. There is dissension among translators about the way to reach this goal, not about the goal: translation is part and parcel of Pombal's import substitution policy. In this way translation is politically legitimated, as it replaces both an uncontrolled importation of foreign literature read in its original idiom, and the barbarization of Portuguese through useless and imperfect loans from other languages.

It comes as no surprise that, in the dedicatory letter to his translation of Elémens $d u$ Commerce, and as a conclusion of a eulogy of Pombal's economic and cultural achievements, Pereira asks the Secretary of State's protection against the critics of 'paraphrastic style':

Espera que V. EXCELLENCIA desculpe os deffeitos que encontrar na traducçaõ, para que esta sua indulgencia sirva da defença contra os que me arguirem o estillo paraphrastico que segui; pareceme que obterei este indulto, quando naõ tem outro fim o meu trabalho, mais que occupar honestamente o tempo, nem outro algum motivo, que o conduzir-me para a fortuna dos meos Patricios, regulado pelas dispoziçoens ajustadissimas, com que V. EXCELLENCIA lhe prepara cada dia novas felicidades. ${ }^{191}$

The paraphrastic style is connected to the idea of a politics of language, consisting of servicing the Nation by translating useful knowledge of alien extraction into a national style which has no rival in the world. Public utility is in this way connected to patriotism, and translation is a patriotic deed. It is useful to observe that in Portuguese, like in other neo-Latin languages, the term '(com)patricio' contains a stronger patriotic connotation than the English most ordinary equivalent 'fellow countryman'.

\section{The Elementos do Commercio: analysis of the translation}

As already mentioned, the translation of Elémens $d u$ commerce was preceded by a dedicatory letter to Pombal. Forbonnais's treatise was the text Pereira was looking for in order to provide a sound scientific foundation to the Marquis' action, and incidentally to that of the Company for which he was working. Forbonnais based his analysis on the assumption that trade had become in modern times 'la base des intérêts politiques $\&$ de l'équilibre des puissances', ${ }^{192}$ because it provided a 'corps politique' with the strength it required to maintain political stability and to defend itself from internal and external enemies. This strength derived from an abundant population, attracted by the 'richesses politiques' a wealthy commercial state could offer. The 'richesses politiques' were of two kinds: 'richesses réelles', i.e. independence from other countries for necessaries and a large surplus of manufactured goods to export abroad, and 'richesses relatives', i.e. the amount of 'richesses de convention' (money) a country was able to attract from abroad, compared to the money attracted by rival countries. ${ }^{193}$ Reaching such a goal was the result of the visible hand of a wise legislator, and of what constituted 'l'art \& la science de l'administration du Commerce politique'. ${ }^{194}$ There was a type of trade that was useful to the body politic, and another that was not useful. Trade was noxious when it introduced in the country 'des marchandises étrangères qui nuisent à la consommation des manufactures nationales'. ${ }^{195}$ The nine principles of commercial policy enounced by 'British authors' were totally endorsed by Forbonnais. ${ }^{196}$ These principles

191 '[The author] hopes that YOUR EXCELLENCY may forgive the imperfections he finds in the translation, so that this indulgence may function as a defence against those who reproached me the paraphrastic style I adopted; I believe I will obtain this forgiveness, as my work has no other aim than honestly spending my time, nor any other motive, than acting for the fortune of my fellow countrymen, regulated by the very appropriate instructions, by which YOUR EXCELLENCY prepares for him every day new opportunities of happiness', Elementos do Commercio, [6].

${ }^{192}$ [François Véron Duverger de Forbonnais], Elémens du commerce (Leyde, 1754), 2 vols, I, 41.

193 [Forbonnais], Elémens du commerce, I, 46-47.

194 [Forbonnais], Elémens du commerce, I, 47.

195 [Forbonnais], Elémens du commerce, I, 48.

196 [Forbonnais], Elémens du commerce, I, 51-52. 
consisted of the traditional maxims of the balance of trade doctrine: ${ }^{197}$ minimising importation and maximising exportation as a way to promote national agriculture and national manufactures, to offer employment to an increasing population ${ }^{198}$ and to increase profit rates, credit and investment. As an admired of Colbert, ${ }^{199}$ Forbonnais was in favour of the domestic production, consumption and exportation of luxuries, although he argued that a balanced development implied the contemporary promotion of agriculture and manufactures ${ }^{200}$ Forbonnais's defence of free competition ${ }^{201}$ was part and parcel of an aggressive commercial policy aiming at maximising the surplus of the general balance of trade. ${ }^{202}$ Domestic competition, together with a low cost of labour ('oeconomie du travail des hommes'), and with low costs of transportation and low interest rates, was a means to secure the competitiveness of national export. ${ }^{203}$ And restrictions to liberty to promote these goals are a necessity, while an absolute free competition that damages the body politic is licence rather than liberty. ${ }^{204}$ Finally, Forbonnais considered colonies as a necessary outcome of the development of European economies ${ }^{205}$ and the obligation 'de consommer les productions du pays de la domination' ${ }^{206}$ as something that was natural to impose them.

In the light of this proximity between the commercial theories contained in the Elémens du commerce, there was no prima facie need to adapt it to the Portuguese context, contrarily to the case of Fénelon. Nevertheless, Pereira performed some manipulation of Forbonnais's treatise. This point can be easily verified by the contrastive analysis of the macrostructure and microstructure of Elementos offered in the remaining part of this section.

At the macrostructural level, table 2 shows that, with the exception of the paratextual components, the translation entirely follows the source text.

Table 2. Comparison of French original and Portuguese translation of Elémens du commerce

Elémens du commerce.

Première partie.

Nulla magis praesens fortuna laborum

Georg. Liv. III

A Leyde

Et se trouve à Paris.

Chez Briasson, rue Saint Jacques.

David l'ainé, rue Saint Jacques.

Le Breton, Imprimeur ordinaire du Roi, rue de la Harpe.

Durand, rue Saint Jacques.

MDCCLIV
Elementos do Commercio,

Traduzidos livremente do francez para o

Portuguez.

Pelo mesmo traductor de Telemaco, e das Orações

Funebres.

Nulla magis praesens fortuna laborum

Parte I.

Lisboa

Na Offic. de Antonio Rodrigues Galhardo.

MDCCLXVI

Com as licenças necessarias

\begin{tabular}{|l|l|}
\hline Première partie & Parte I. \\
\hline Avertissement [3 pages without number] & $\begin{array}{l}\text { Ao ILL. }{ }^{\text {MO }} \text { e EX. }{ }^{\text {MO }} \text { SENHOR SEBASTIAÕ } \\
\text { JOZE' DE CARVALHO, E MELLO Conde, e Senhor } \\
\text { de Oueiras, Ministro, e Secretario de Estado de sua } \\
\text { Magestade Fidelissima \&c. \&c. \&c. [6 pages] }\end{array}$ \\
\hline & Licenças [2 pages] \\
\hline & Index das erratas [1 page] \\
\hline
\end{tabular}

197 [Forbonnais], Elémens du commerce, I, 72-78, 244-76.

198 [Forbonnais], Elémens du commerce, I, 54.

199 [Forbonnais], Elémens du commerce, I, 40-41.

200 [Forbonnais], Elémens du commerce, I, 55-58.

201 [Forbonnais], Elémens du commerce, I, 88-96.

202 [Forbonnais], Elémens du commerce, I, 80.

203 [Forbonnais], Elémens du commerce, I, 62.

204 [Forbonnais], Elémens du commerce, I, 79.

205 [Forbonnais], Elémens du commerce, I, 351-400

206 [Forbonnais], Elémens du commerce, I, 7. 


\begin{tabular}{|c|c|}
\hline $\begin{array}{l}\text { Table des chapitres. } \\
\text { Première partie }\end{array}$ & $\begin{array}{l}\text { Index dos capitulos } \\
\text { Parte I. }\end{array}$ \\
\hline $\begin{array}{l}\text { Chapitre I. } \\
\text { Du Commerce en général.* [pp. 1-87; 14,8\%] }\end{array}$ & $\begin{array}{l}\text { Capitulo I. } \\
\text { Do Commercio em geral [pp. 1-70;17,4\%] }\end{array}$ \\
\hline $\begin{array}{l}\text { Chapitre II. } \\
\text { De la Concurrence.* [pp. 88-96; 1,5\%] }\end{array}$ & $\begin{array}{l}\text { Capitulo II. } \\
\text { Da Concorrencia [pp. } 71-77 ; 1,7 \% \text { ] }\end{array}$ \\
\hline $\begin{array}{l}\text { Chapitre III. } \\
\text { De l'Agriculture. [pp. 97-240; 24,5\%] }\end{array}$ & $\begin{array}{l}\text { Capitulo III. } \\
\text { Da Agricultura [pp. } 77-145 ; 17,2 \% \text { ] }\end{array}$ \\
\hline \multirow[t]{2}{*}{$\begin{array}{l}\text { Chapitre IV. Des Manufactures ou du travail } \\
\text { industrieux. [pp. 241-312;12,2\%] }\end{array}$} & $\begin{array}{l}\text { Capitulo IV. } \\
\text { Das Manufacturas, ou do trabalho industrioso [pp. } \\
\text { 145-97; } 13,2 \% \text { ] }\end{array}$ \\
\hline & Parte II. \\
\hline $\begin{array}{l}\text { Chapitre V. } \\
\text { De la Navigation. [pp. } 312-50 ; 6,6 \% \text { ] }\end{array}$ & $\begin{array}{l}\text { Capitulo V. } \\
\text { Da Navegaçaõ [pp. 5-32; 7\%] }\end{array}$ \\
\hline $\begin{array}{l}\text { Chapitre VI. } \\
\text { Des Colonies. [pp. } 351-400,8,5 \% \text { ] }\end{array}$ & $\begin{array}{l}\text { Capitulo VI. } \\
\text { Das Colonias [pp. 32-58; 6,7\%] }\end{array}$ \\
\hline \multicolumn{2}{|l|}{$\begin{array}{l}\text { Errata } \\
\text { de la première Partie [1 page without number] }\end{array}$} \\
\hline \multicolumn{2}{|l|}{$\begin{array}{l}\text { Errata } \\
\text { de la seconde Partie [1 page without number] }\end{array}$} \\
\hline \multicolumn{2}{|l|}{ Seconde partie. } \\
\hline $\begin{array}{l}\text { Chapitre VII. } \\
\text { Des Assurances.* [pp. 1-24; 4,1\%] }\end{array}$ & $\begin{array}{l}\text { Capitulo VII. } \\
\text { Das Seguranças do risco [pp. 58-69; 3\%] }\end{array}$ \\
\hline $\begin{array}{l}\text { Chapitre VIII. } \\
\text { Du Change.* [pp. 25-66; 7,1\%] }\end{array}$ & $\begin{array}{l}\text { Capitulo VIII. } \\
\text { Dos Cambios [pp. 69-90; 5,5\%] }\end{array}$ \\
\hline $\begin{array}{l}\text { Chapitre IX. } \\
\text { De la Circulation de l'Argent. [pp. 67-172; } \\
18,0 \% \text { ] }\end{array}$ & $\begin{array}{l}\text { Capitulo IX. } \\
\text { Da Circullaçao do dinheiro [pp. 90-154, 16,2\%] }\end{array}$ \\
\hline $\begin{array}{l}\text { Chapitre X. } \\
\text { Du Crédit. [pp. 173-220; 8,2\%] }\end{array}$ & $\begin{array}{l}\text { Capitulo X. } \\
\text { Do Credito [pp. 154-80; 6,7\%] }\end{array}$ \\
\hline $\begin{array}{l}\text { Chapitre XI. } \\
\text { Du Luxe. [pp. } 221-43 ; 3,9 \% \text { ] }\end{array}$ & $\begin{array}{l}\text { Capitulo XI. } \\
\text { Do Luxo [pp. 180-192; 3,2\%] }\end{array}$ \\
\hline \multirow[t]{3}{*}{ De la Balance du Commerce. [pp. 244-76; 5,6\%] } & $\begin{array}{l}\text { Capitulo XII. } \\
\text { Da Balança do Commercio [pp. 193-205; 3,2\%] }\end{array}$ \\
\hline & Index das erratas \\
\hline & $\begin{array}{l}\text { Index dos capitulos } \\
\text { Parte II. }\end{array}$ \\
\hline [Total pages of main text $=588]$ & [Total pages of main text $=402]$ \\
\hline * (Chapters with a star derive from Encyclopédie) & \\
\hline
\end{tabular}

Both the original and the translation are divided into two parts. However, Pereira reorganised the whole by shifting chapters 5 and 6 from Part 1 to Part 2, maybe in an attempt to divide the subject in a more rational way. Comparing this text with the typical division in four parts of the treatises and textbooks of political economy in the $19^{\text {th }}$ century, we can observe that Pereira concentrated the preliminaries and the theory of production in Part 1, while he allocated to Part 2 the theory of circulation (chapters 5 to 10) and the theory consumption (ch. 11), while the final chapter 12 contained the main policy recommendations (no chapters were explicitly devoted to the theory of 
distribution).

Secondly, the front page of the Portuguese version defines it as a 'free translation'. The quantitative information provided by table 2 suggests that Pereira's adaptation, in Amaro de Roboredo's terms, was closer to a 'compêndio' [compendium] ${ }^{207}$ than to a 'declaração parafrástica' ${ }^{208}$ [paraphrastic declaration]. This fact is suggested by the smaller number of pages of the translation, although the different layout can explain part of this difference. However, percentages reveal that the condensation was more or less effective depending on the subject. A few examples of microstructural analysis can show how Pereira actually behaved in translating and adapting the source text.

It may be useful to start from the conclusion of our analysis. Pereira's attitude vis-à-vis the translation of Elémens can be characterised as a mixed strategy. Firstly, there are many parts that it would be more appropriate to classify as translation 'por cláusulas' than as paraphrasis, as the main differences lie in the structure of sentences and in subordination. Secondly, there are entire parts that are completely omitted. Omitted parts range from a few lines to entire paragraphs or groups of paragraphs (and pages). Short omissions are very often justified by reasons of synthesis, and in a few cases by reasons of political prudence, or to adapt the text to the target national context. Longer omissions are generally more strategical: either they aim at adapting the text to a Portuguese readership, for example by omitting historical descriptions referred to France, or they are again motivated by reasons of political prudence. Finally, truly paraphrastic manipulations are much more limited than one could expect. Indeed, the cases of paraphrasis or 'paraphrastic declaration' consist of some very short additions through which the translator either explains a notion that may sound unfamiliar to domestic readers (in some cases this service is rendered by a translator's footnote), or adds some political remarks. The latter, in turn, are introduced either to make a comment, or, once again, to avoid problems with censorship and government. On the whole, condensation largely prevails on enlargement.

Since these strategies are equally distributed along the text, we take as an illustration chapter 6 'On Colonies', which represent a hot problem in the Portuguese economic literature of the modern period. The following example illustrates the cases of translation 'by clauses':

A moins que l'état ne se charge de leur dépense, il faut qu'elles soient sous la dépendance d'une compagnie riche \& exclusive en état de féconder $\&$ de suivre des projets politiques. Dans l'Inde on ne regarde comme marchands que les Anglois parmi les grandes nations de l'Europe qui y commercent; sans doute parce qu'ils y sont les moins puissans en possessions. ${ }^{209}$
Se o Estado se naõ encarregar da sua dispeza, estaraõ entaõ na dependencia d'huma companhia rica, e excluziva, capaz de ajudar, e seguir os intentos politicos. Na India naõ saõ reputados por mercadores mais que os Inglezes entre as naçoens da Europa, que ahi commerceaõ; sem duvida, porque saõ os menos poderozos en possessoens. ${ }^{210}$

There are no substantive differences between the two texts. But some stylistic changes seem to be justified to make the translation closer to the target language. An example is the opening conditional sentence, whose protasis is introduced in the French version by the prepositional locution 'a moins que', and in the Portuguese translation by the simple preposition 'se'. The apodosis of the same conditional sentence is composed in the French original by an impersonal verb ('il faut que') followed by a completive sentence functioning as its subject. The Portuguese translation is made up by a simple sentence strengthened by the adverb 'então'. The remaining parts of this passages are quite similar. We can only notice that the term 'féconder' [fecundate] is replaced in the translation by 'ajudar' [help], and that the adjective 'grandes' is omitted in the Portuguese version.

\footnotetext{
207 'Se reduzires a hüa clausula muitas de muitas palavras cada hüa: ou se reduzires muitos conceitos a hum mais principal, ou na mesma lingua, ou em diversa', Roboredo, Porta de Linguas, 24.

208 '...se trasladares hüa clausula em duas, ou mais, usando de mais frases diversas: ou se declarares o mesmo conceito com dous ou mais', Roboredo, Porta de Linguas, 24-5.

209 [Forbonnais], Elémens du commerce, I, 355-56.

210 [Forbonnais], Elementos do Commercio, II, 36.
} 
An example of short omission justified by simple reasons of synthesis is the following:

Cette possession exigeoit des conquêtes, \& tout ce qui appartient à son esprit; elle exigeoit dans le trafic une unité de vûes \& de conduite, parce que le grand principe de la concurrence intérieure n'est principalement pratiqué qu'en faveur de la concurrence extérieure. ${ }^{211}$
Essa Possessaõ requeria conquistas, e pedia no Commercio huma uniaõ de dezejos, e de conducta, porque o grande principio da concorrencia interior naõ he principalmente praticado mais, que a favor da concorrencia exterior. ${ }^{212}$

There are cases in which omissions are justified by contextual adaptation. For example, when listing the main sources of profitable trade with colonies, Pereira omits those articles that do not belong to the Portuguese trade with its own colonies:

...une pareille somme en sucres, indigots, caffés, cottons, tabacs, soies, ris, brais, gaudrons, pelletteries, mâtures, dont une partie se réexporte, nourrira une multitude infinie de matelots, charpentiers, galfats, \&c. ${ }^{213}$
... huma igual quantia de assucares, cafés, algodoens, tabacos, sedas, e arrozes, de que tudo grande parte se reexporta, sustentara infinitos homens em diversos officios. ${ }^{214}$

The last sentence of this passage also presents a type of paraphrastic variation: a list of professions is translated by a periphrasis which offers a generalisation of all possible professions connected to colonial trade.

An example of omission motivated by political prudence is the following:

Le bas prix dépendra encore su bon marché des Nègres, du fret, de l'intérêt de l'argent, tous effets de la concurrence des négocians. ${ }^{215}$
O baixo preço depende da moderaçaõ dos fretes, e do interesse do dinheiro, effeitos todos de concorrencia dos negociantes. ${ }^{216}$

The slave trade was one of the most lucrative businesses of the Company for which Pereira worked. But it was also a controversial issue, that the translator preferred to avoid in offering his version of Forbonnais's treatise. The same prudence is also the cause of a long omission of four paragraphs (covering 4 pages) of the original devoted to the trade of 'ce malheureux Africains', despite Forbonnais's neutral endorsement of it as a necessity. ${ }^{217}$ Another significant omission is that of pages 378-79 of the original, in which Forbonnais reports Josiah Child's opinion that the depopulation of Spain was caused more by the inquisition than by emigration to colonies. In this case Pereira probably intended to avoid any problem with the Portuguese religious censorship.

This case is not isolated, and offers us the opportunity to introduce another case of paraphrastic approach. In chapter 1, Forbonnais describes the flourishing trade in the Low Countries in the $16^{\text {th }}$ century, when Philip II of Habsburg accessed to the throne. Trade, he says 'étoit immense dans ces provinces, lorsque Philippe II. le troubla par l'établissement de nouveaux impôts et $\underline{\&}$ de l'inquisition' ${ }^{218}$ Pereira's translation sounds as follows: 'Florescente se achava elle naquellas provincias quando Filippe II. o perturbou pelo estabelecimento de novos impostos, e pelo Catholico zelo, com que quiz purificar a Religiaõ' ${ }^{219}$ Through this periphrasis Pereira avoided mentioning the Inquisition and offered a less pejorative description of the king's action in religious matters. In the

\footnotetext{
211 [Forbonnais], Elémens du commerce, I, 356.

212 [Forbonnais], Elementos do Commercio, II, 37.

213 [Forbonnais], Elémens du commerce, I, 381.

214 [Forbonnais], Elementos do Commercio, II, 51.

215 [Forbonnais], Elémens du commerce, I, 289.

216 [Forbonnais], Elementos do Commercio, II, 54.

217 [Forbonnais], Elémens du commerce, I, 382-86.

218 [Forbonnais], Elémens du commerce, I, 30.

219 [Forbonnais], Elementos do Commercio, I, 25.
} 
same chapter Forbonnais did not spare his critiques to the Portuguese colonisation. But significantly Pereira did not omit or modify these portions of text, possibly because Pombal's colonial policy was currently perceived as a reform of old contradictions. ${ }^{220}$

As to other cases of paraphrasis, they play a simpler rhetorical role. Among them there are various cases of hendiadys:

\author{
Elémens du commerce \\ 'à l'abri de l'insulte' (359) \\ 'les subjuguer' (362) \\ ‘surprises’ (363)
}

\author{
Elementos do Commercio \\ 'esentas e livres do insulto' (II, 39) \\ 'subordinallos e sujeitallos' (II, 40) \\ 'astucias, enganos, embuscadas' (II, 40)
}

There also are various cases of variatio, like the following:

\author{
Elémens du commerce \\ 'ajoutoient' (359) \\ 'commerce' (364)
}

\section{Elementos do Commercio \\ 'establecerem' (II, 38) \\ 'concorrencia' (II, 42)}

A replacement by metonymy is 'forces navales' ${ }^{221}$ translated as 'navegaçaõ'. ${ }^{222}$

More complex paraphrases occur only occasionally. An example is the following, in which Forbonnais deals with the ways of governing the population of the colonies:

Cependant l'impression de la crainte doit être établie d'un pas égal, lorsqu'ils se refusent à ce qui est convenu ou raisonnable. ${ }^{223}$
Com tudo a impressaõ do temor deve ser establecida com igualdade quando desprezaõ a docilidade e brandura. ${ }^{224}$

Chapter 6 also contains an interesting footnote (the whole book contains circa twenty similar additions), aiming at explaining the meaning of 'Commercio furtivo', translating 'commerce interloppe': ${ }^{225}$ 'He o que fazem os navios dos particulares de baixo do nome das Companhias sem terem alcançado para isso permissaõ'. ${ }^{226}$ This was a hot issue for the secretary of one of the chartered companies instituted by Pombal, and the footnote allowed Pereira to underline it.

There is a last question concerning this translation that deserves some comments. Introducing to to Pombal his translation, Pereira declared what follows:

OFFEREÇO A V. EXCELlENCIA, vertidos no idioma Portuguez, os Elementos do Commercio, que compoz Carlos Seconda de Montesquieu, Varaõ que em tanto que no mundo existir a veneraçaõ dos Sabios, durará para sempre impresso na lembrança dos homens o seu nome [sic] pela grandeza das suas obras. ${ }^{227}$

${ }^{220}$ See for example [Forbonnais], Elémens du commerce, I, 34, where Forbonnais refers to 'les rois Indiens qui gemissoient sous le joug impérieux des Portugais': a pejorative remark that is maintained by the translator: 'os Reis Indiáticos que gemiaõ debaixo do jugo imperiozo dos Portuguezes'; see [Forbonnais], Elementos do Commercio, I, 28.

221 [Forbonnais], Elémens du commerce, I, 359.

222 [Forbonnais], Elementos do Commercio, II, 39.

223 [Forbonnais], Elémens du commerce, 362.

224 [Forbonnais], Elementos do Commercio, II, 41.

${ }^{225}$ [Forbonnais], Elémens du commerce, 380.

226 'It is the trade done by private ships under the name of the Company, without receiving permission for that'; see [Forbonnais], Elementos do Commercio, II, 51.

227 'I OFFER to Y. EXCELLENCY, translated into Portuguese, the Elements of Commerce, composed by Charles Secondat de Montesquieu, a man who, so long as there will be in the world a veneration for learned people, whose name [sic] will remain printed in the memory of men for the greatness of his works'; see [Forbonnais], Elementos do Commercio, I, [1-2]. 
Forbonnais's Elémens were published anonymously, and Pereira was convinced that it was the work of Montesquieu. The question is why he made such a mistake. In The Passions and the Interests, ${ }^{228}$ Albert O. Hirschman attracted the attention of scholars on the so called 'doux commerce thesis', formulated by Montesquieu in books XX-XXI of Esprit de lois. Montesquieu argued that 'c'est presque une règle générale, que partout où il $\mathrm{y}$ a des moeurs douces, il ya du commerce; $\&$ que partout où il y a du commerce, il a des moeurs douces' ${ }^{229}$ As a consequence, '[1]'effet naturel du commerce est de porter à la paix. Deux nations qui négocient ensemble, se rendent réciproquement dépendantes: si l'une a intérêt d'acheter, l'autre a intérêt de vendre; \& toutes les unions sont fondées sur des besoins mutuels' ${ }^{230}$ The Esprit des lois was certainly a source for Forbonnais, who opened his treatise with some maxims that recalled the doux commerce thesis:

La providence infinie dont la nature est l'ouvrage, a voulu par la variété qu'elle y répand mettre les hommes dans la dépendance les uns des autres. L'être suprême en a formé les liens, afin de porter les peuples à conserver la paix entr'eux, à s'aimer, \& afin de réunir le tribut de leurs louanges, en leur manifestant son amour \& sa grandeur, par la connoissance des merveilles dont il a rempli l'univers. C'est ainsi que les vues et les passions humaines rentrent dans l'ordre inaltérable des décrets éternels. ${ }^{231}$

No translation of Montesquieu's chef-d'oeuvre circulated in Portugal in the $18^{\text {th }}$ century. The first translation appeared in Brazil only in 1982. An edict of the Real Mesa Censória of 22 April 1771 prohibited the circulation and translation of Lettres persanes ${ }^{232}$, while translations of Considérations sur les causes de la grandeur des Romains et de leur décadence and of the 'Pensées' published in Journal encyclopédique dated from a later period (1780 and 1789 respectively). ${ }^{233}$ However Pereira may have been familiar with the French original of Montesquieu's main work. There were other similarities between the Elémens and the two books of Esprit devoted to commerce that might have captured the attention of Pereira: chapter 1 of book XX of Esprit was entitled 'Du commerce', while chapter 1 of Elémens was entitled 'Du commerce en général'. The historical outline contained in this chapter was clearly indebted to book XXI of Esprit. The analysis of free competition in chapter 2 of Elémens showed some parallelisms with chapters 12 and 13 of book XX of Esprit, where Montesquieu argued that '[1]a liberté du commerce n'est pas une faculté accordée aux négocians de faire ce qu'ils veulent; ce seroit bien plutôt servitude', ${ }^{234}$ and approved the protectionist policy introduced by Great Britain, arguing that '[e]lle gêne le négociant; mais c'est en faveur du commerce'. Forbonnais's arguments on colonial empire were similar to those contained in chapter 21 of book XXI of Esprit. And the examples could be multiplied ad libitum. Maybe the misunderstanding was created by Montesquieu himself, who at the beginning of book XX had given the impression that he had in mind to write a more extensive work on the subject of commerce:

Les matières qui suivent demanderoient d'être traitées avec plus d'étendue; mais la nature de cet ouvrage ne le permet pas. Je voudrois couler sur une rivière tranquille; je suis entraîné par un torrent. ${ }^{235}$

Thus Pereira translated Forbonnais believing he was introducing Montesquieu's politico-economic

228 (Princeton, 1977).

229 Charles Secondat de Montesquieu, De l'Esprit des loix, 4 vols (Londres, 1757), II, 238.

230 Idem, II, 239-40.

231 [Forbonnais], Elémens du commerce, I, [1-2].

232 See Catálogo de livros defesos neste Reino ... para servir no Expediente da Casa da Revisão, ANTT, Real Mesa Censória, liv. 12, f. 43. For further details on censorship in Portugal in the 18th century see Maria Adelaide Salvador Marques, A Real Mesa Censória e a cultura nacional (Coimbra, 1963); Maria Adelaide Salvador Marques, Pombalismo e cultura média: meios para um diagnóstico através da Real Mesa Censória (Lisboa, 1982); and Giuseppe Marcocci and José Pedro Paiva, História da Inquisição Portuguesa 1536-1821 (Lisboa, 2013).

${ }^{233}$ Charles Secondat de Montesquieu, Considerações sobre as Causas da Grandeza e Decadencia dos Romanos (Lisboa, 1780); 'Pensamentos extrahidos dos manuscriptos de Montesquieu transcritos do Jornal Encyclopedico de Bouillon' in Jornal Encyclopedico, Feb. 1789, 228-35.

234 Montesquieu, De l'Esprit des loix, II, 253-54.

235 Idem, II, 238. 
though into his country as a contribution to the defence and dissemination of Pombal's trade policy.

\section{Conclusions}

José Manuel Ribeiro Pereira probably died in $1797 .{ }^{236}$ His reputation was severely questioned in the $19^{\text {th }}$ century by Inocêncio da Silva's lapidary comment: 'Todas estas traducçoes, feitas no gosto da do Telemaco, são tidas na mesma conta. Ninguem as procura, ninguem as lêe, ${ }^{237}$. In the light of Inocêncio's opposition to paraphrasis and of his contempt for Pereira's original literary attempts, this conclusion is not surprising. However it is perhaps too harsh at least for the contribution Pereira gave to the dissemination of political economy in Portugal in the $18^{\text {th }}$ century. Thanks to his privileged position and to the approval of Pombal, he was able to offer the translation of a work, the Elémens du commerce, that contributed to influencing a rising public opinion in favour of the Marquis' policies. As shown in this paper, this book was one of the few translations of economic works that appeared in Portugal in the $18^{\text {th }}$ century. Pereira's pro-Pombaline adaptation of Aventures de Télémaque proved to be a courageous defence of Pombal's action after his dismissal. His use of the paraphrastic method was considered by him as part and parcel of a patriotic service he aimed to render to his fellow countrymen. It was the way in which he aimed at nationalising foreign literature. In the context of Portugal during the reign of D. José, such an attempt is surprisingly isomorphic to the commercial policies of Pombal, as it aims at substituting the importation of foreign literature with works originally produced in Portugal for a domestic readership.

\section{Acknowledgments}

This paper is a product of the LLP/Erasmus Sub Programme Multilateral Project 'EE-T. Economics e-Translations into and from European Languages, An Online Platform' (518297-LLP-1-2011-ITERASMUS-FEXI). It is also presented in the framework of the Prin 2010-2011 'Libertà dei moderni. Processi di civilizzazione nel lungo illuminismo (1750-1850): commercio, politica, cultura, colonie' (20108KZTPX_004). The authors wish to thank the coordinator of the Old Rare Books Department of the Biblioteca Municipal de Viseu, Dr. Teresa Almeida, for her invaluable help in making available a considerable part of the printed materials on which this paper is based, and the archivists of the Arquivio Nacional da Torre do Tombo, Lisbon, for their kind and expert advice during our research. The authors are also indebted to Antonella Alimento, José Luis Cardoso, João Paulo Silvestre, Evelina Verdelho and Telmo Verdelho for their comments and suggestions at different stages of their inquiry. Usual disclaimers apply.

36 Silva, Diccionario, V, 9.

237 Silva, Diccionario, V, 10 